\title{
Recent Progress in Biochar-Based Photocatalysts for Wastewater Treatment: Synthesis, Mechanisms, and Applications
}

\author{
Jiali Cui *, Feng Zhang, Hongyan Li, Jianguo Cui, Yatao Ren and Xiaochen Yu \\ College of Environmental Science and Engineering, Taiyuan University of Technology, Jinzhong 030600, China; \\ zhangfeng@tyut.edu.cn (F.Z.); lihongyan002@tyut.edu.cn (H.L.); cuijianguo@tyut.edu.cn (J.C.); \\ renyatao@163.com (Y.R.); 13603510061@163.com (X.Y.) \\ * Correspondence: cuijiali@tyut.edu.cn
}

Received: 31 December 2019; Accepted: 24 January 2020; Published: 4 February 2020

\begin{abstract}
Biochar (BC) is a carbon-rich material produced from pyrolysis of biomass. In addition to its low toxicity, environmental compatibility, and low cost, BC has the desired advantages of well-developed mesoporous structure and abundant surface functional groups. In recent years, $\mathrm{BC}$-based photocatalysts (BCPs) have played a significant role in many environmental fields. In this paper, we highlight the current progress and several exciting results of $\mathrm{BCPs}$ by focusing on their synthesis, characterization, mechanisms, and applications in wastewater treatment. Details on various preparation methods include sol-gel, hydrothermal/solvothermal, ultrasound, calcination, and in situ methods are summarized and discussed. The underlying mechanisms and the applications of BCPs for different semiconductors are reviewed. Furthermore, some future trends and potentials are outlined.
\end{abstract}

Keywords: biochar; photocatalyst; wastewater; applications; mechanisms; preparation method

\section{Introduction}

Photocatalysis has emerged into an efficient and viable technique for purification of wastewater. Various nanoparticles such as $\mathrm{TiO}_{2}, \mathrm{RuO}_{2}, \mathrm{SiO}_{2}, \mathrm{ZrO}_{2}, \mathrm{ZnO}, \mathrm{CdS}$, and $\mathrm{ZnS}$ have been used as semiconductor photocatalysts [1]. Despite the excellent functionality, high photostability, and non-toxicity properties, the quick recombination of hole-electron pairs and poor visible-light response limit the photocatalytic performance of semiconductors [2].

To date, considerable attempts have been made to improve the photocatalytic ability using modification of $\mathrm{TiO}_{2}$. In the beginning, metal or metal oxides were used to dope $\mathrm{TiO}_{2}$ to lower the bandgap energy and motivate the visible-light response. However, metal-based doping photocatalysts increase the carrier recombination rate, induce the photocorrosion, secondary pollution and subject to poor thermal stability [3,4]. The high price also hinders its wide application under visible light. In 2001, Asahi [5] first synthesized a non-metal-semiconductor composite by doping nitrogen. Nitrogen can extend the optical absorption spectra of $\mathrm{TiO}_{2}$ to $500 \mathrm{~nm}$ without reducing ultraviolet light. Subsequently, researchers began to study various non-metal-based photocatalysts [6,7]. Doping of semiconductors (e.g., $\mathrm{TiO}_{2}, \mathrm{ZnO}, \mathrm{ZrO}_{2}$ ) with non-metals such as C [8], S [9,10], N [11], B [12], F [13,14] and P [15] helped to improve the photocatalytic efficiency. Moreover, non-metals could extend the visible region absorption close to the edge of the valence band, which is more advantageous than metal in improving the visible-light response [16,17].

Among them, combining semiconductors with carbonaceous nanomaterials has been increasingly investigated due to their tunable structural, electrical properties, a wide range of visible-light absorption 
and enhanced electronic conductivity [4]. Khan et al. [18] first achieved the doping of carbon in the natural gas flame by heating the Ti metal. It significantly changed the absorption characteristics of the catalyst to visible light. Its photoelectric conversion efficiency can reach $8.35 \%$, compared with that of pure $\mathrm{TiO}_{2}(1.08 \%)$. Sakthivel et al. [19] found that the photocatalytic effect of carbon doping was five times higher than that of nitrogen-doped samples. Chen et al. [20] compared the photocatalytic activities of carbon and nitrogen-doped $\mathrm{TiO}_{2}$ samples under visible-light irradiation. They suggested the higher photocatalytic activity was due to the synergistic effect of carbon and nitrogen atoms. Wang et al. [21] theoretical calculation results demonstrated the forbidden band gap of $\mathrm{C}-\mathrm{TiO}_{2}$ was narrowed down to $2.35 \mathrm{eV}$. They proposed that the introduction of carbon can narrow the band gap, thus enhancing the photocatalytic performance. However, the widespread application of carbon-based photocatalysts was most limited because of the high price and complicated fabrication methods of these materials. Thus, the development of cheap, sustainable and efficient photocatalysts will be of great interest (Figure 1).

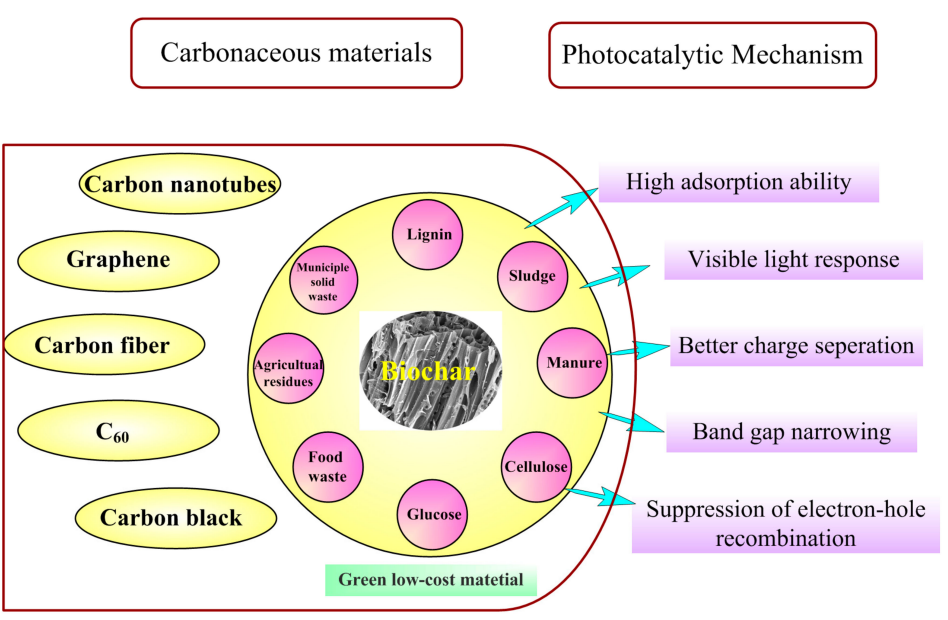

Figure 1. Carbonaceous materials and the mechanisms of BCPs on the treatment of wastewater.

Biochar (BC) is produced through pyrolysis, gasification and hydrothermal carbonization of biomass. The biomass feedstocks include wood materials, forestry products, sludge, manure, agricultural residue and organic wastes. In comparison with most conventional activated carbon, biochar possesses a well-developed mesoporous structure and abundant surface functional groups. Furthermore, it can be served as a versatile catalyst or catalyst support [22]. In recent years, biochar-based photocatalysts (BCPs) have received great attention in various environmental fields [23-27]. Some of those recently reported $\mathrm{BCPs}$ were $\mathrm{TiO}_{2}$-coconut shell [28], $\mathrm{TiO}_{2}-\mathrm{Salvinia}$ molesta [29], $\mathrm{TiO}_{2}$-reed straw [30], $\mathrm{TiO}_{2}$-ramie char [31], $\mathrm{TiO}_{2}$-corn cob [32], $\mathrm{TiO}_{2}$-paper sludge and wheat husks [33], $\mathrm{TiO}_{2}$-bamboo [34,35], $\mathrm{ZnO}$-waste biomass [36], g- $\mathrm{C}_{3} \mathrm{~N}_{4} / \mathrm{FeVO}_{4}$-pinus roxbu rghii [37], $\mathrm{Bi}_{2} \mathrm{O}_{3}$-corn cobs [38], $\mathrm{TiO}_{2}$-walnut shells [39], $\mathrm{TiO}_{2}$-olive pits and $\mathrm{TiO}_{2}$-wood shaving [40], $\mathrm{TiO}_{2}$-wood pellets [41], and $\mathrm{TiO}_{2}$-plum stones [42], etc.

This review presents the recent development of typical BC-based photocatalysts used for wastewater treatment. Notably, a significant proportion of the review concerns the synthesis, mechanisms and applications of BCPs reported in literature, and provides useful suggestions for novel $\mathrm{BCPs}$ in photodegradation of wastewater.

\section{Synthesis}

The synthesis route for BCPs has great influence on photocatalytic performance. Various efficient methods and approaches have been reported for the synthesis of BCPs (summarized in Table 1), including sol-gel [28-32,43,44], hydrothermal/solvothermal [36,38,39,45-53], ultrasound [40,41,54,55], calcination [34,56-58] and in situ methods [35,59], etc. 
Table 1. Synthesis and the application of BCPs.

\begin{tabular}{|c|c|c|c|c|c|c|}
\hline BCPs & Biomass & Pollutants & Synthesis Route & Working Conditions & Performance & Refs \\
\hline $\mathrm{BC}-\mathrm{TiO}_{2}$ & Coconut shell & $\begin{array}{l}\text { Reactive Brilliant Blue } \\
\text { KN-R }\end{array}$ & Sol-gel & $\begin{array}{c}{[\mathrm{KN}-\mathrm{R}]=30 \mathrm{mg} \cdot \mathrm{L}^{-1}} \\
{[\mathrm{BCPs}]=6 \mathrm{~g} \cdot \mathrm{L}^{-1}} \\
\text { Ultraviolet }(\mathrm{UV}) \text { light }\end{array}$ & $\begin{array}{c}99.71 \%(\mathrm{pH}=1,60 \mathrm{~min}) \\
96.99 \%(\mathrm{pH}=11,60 \mathrm{~min})\end{array}$ & [28] \\
\hline $\mathrm{BC}-\mathrm{TiO}_{2}$ & Salvinia molesta (SM) & $\begin{array}{l}\text { Acid Orange } 7 \\
\text { (AO7) }\end{array}$ & $\begin{array}{c}\text { Sol-gel } \\
\text { Mechanical mixing }\end{array}$ & $\begin{array}{c}{[\mathrm{AO}]=20 \mathrm{mg} \cdot \mathrm{L}^{-1}} \\
{[\mathrm{BCPs}]=0.25 \mathrm{~g} \cdot \mathrm{L}^{-1}} \\
\mathrm{UV} \text { light }\end{array}$ & $57.6 \%(180 \mathrm{~min})$ & [29] \\
\hline $\mathrm{BC}-\mathrm{TiO}_{2}$ & Reed straw (RS) & $\begin{array}{c}\text { Sulfamethoxazole } \\
\text { (SMX) }\end{array}$ & Sol-gel & $\begin{array}{c}{[\mathrm{SMX}]=10 \mathrm{mg} \cdot \mathrm{L}^{-1}} \\
{[\mathrm{BCPs}]=1.25 \mathrm{~g} \cdot \mathrm{L}^{-1}} \\
\mathrm{UV} \text { light }\end{array}$ & $91.27 \%(180 \mathrm{~min})$ & [30] \\
\hline $\mathrm{BC}-\mathrm{TiO}_{2}$ & Ramie char & Safranine $\mathrm{T}(\mathrm{ST})$ & Modified sol-gel & $\begin{array}{c}{[\mathrm{ST}]=500 \mathrm{mg} \cdot \mathrm{L}^{-1}} \\
{[\mathrm{BCPs}]=2 \mathrm{~g} \cdot \mathrm{L}^{-1}} \\
\mathrm{UV} \mathrm{light}\end{array}$ & $226.7 \mathrm{mg} \cdot \mathrm{g}^{-1}(120 \mathrm{~min})$ & [31] \\
\hline $\mathrm{BC}-\mathrm{TiO}_{2}$ & Corn cob (CC) & SMX & Sol-gel & $\begin{array}{c}{[\mathrm{SMX}]=10 \mathrm{mg} \cdot \mathrm{L}^{-1}} \\
{[\mathrm{BCPs}]=5 \mathrm{~g} \cdot \mathrm{L}^{-1}} \\
\mathrm{UV} \text { light }\end{array}$ & $\begin{array}{c}91 \% \text { (removal efficiency, } \\
360 \mathrm{~min} \text { ) } \\
81 \% \text { (mineralization, } \\
360 \mathrm{~min} \text { ) }\end{array}$ & [32] \\
\hline $\mathrm{BC}-\mathrm{TiO}_{2}$ & Sugarcane bagasse & Methyl orange (MO) & Sol-gel & $\begin{array}{c}{[\mathrm{MO}]=3 \times 10^{-5} \mathrm{~mol} / \mathrm{L}} \\
{[\mathrm{BCPs}]=1 \mathrm{~g} \cdot \mathrm{L}^{-1}} \\
\text { Visible light }\end{array}$ & $95.0 \%$ (300 min) & [43] \\
\hline $\mathrm{BC}-\mathrm{Zn} / \mathrm{TiO}_{2}$ & Reed straw & SMX & Modified sol-gel & $\begin{array}{c}{[\mathrm{SMX}]=10 \mathrm{mg} \cdot \mathrm{L}^{-1}} \\
{[\mathrm{BCPs}]=1.25 \mathrm{~g} \cdot \mathrm{L}^{-1}} \\
\text { Visible light }\end{array}$ & $81.21 \%(180 \mathrm{~min})$ & [44] \\
\hline $\mathrm{BC}-\mathrm{ZnO}$ & Waste biomass & Orange $\mathrm{G}$ dye (OG) & Hydrothermal & $\begin{array}{c}{[\mathrm{OG}]=50 \mathrm{mg} \cdot \mathrm{L}^{-1}} \\
{[\mathrm{BCPs}]=1 \mathrm{~g} \cdot \mathrm{L}^{-1}} \\
\mathrm{UV} \text { and Visible light }\end{array}$ & $\begin{array}{c}\text { 88.4\% (Visible light) } \\
94.1 \% \text { (UV light) }\end{array}$ & [36] \\
\hline $\mathrm{BC}-\mathrm{TiO}_{2}$ & Walnut shells & MO & Hydrothermal & $\begin{array}{c}{[\mathrm{MO}]=20 \mathrm{mg} \cdot \mathrm{L}^{-1}} \\
{[\mathrm{BCPs}]=0.25 \mathrm{~g} \cdot \mathrm{L}^{-1}} \\
\mathrm{UV} \text { light }\end{array}$ & $\begin{array}{c}92.45 \% \text { (decolorization, } \\
150 \text { min) } \\
76.56 \% \text { (mineralization, } \\
150 \text { min) }\end{array}$ & [39] \\
\hline $\begin{array}{c}\mathrm{BC}-\mathrm{Bi}_{2} \mathrm{O}_{2} \mathrm{CO}_{3} / \\
\mathrm{g}-\mathrm{C}_{3} \mathrm{~N}_{4} / \mathrm{CoFe}_{2} \mathrm{O}_{4}\end{array}$ & Prunus dulcis & Paraquat (PQT) & Hydrothermal & $\begin{array}{c}{[\mathrm{PQT}]=20 \mathrm{ppm}} \\
{[\mathrm{BCPs}]=0.5 \mathrm{~g} \cdot \mathrm{L}^{-1}} \\
\text { Visible light and sunlight }\end{array}$ & $\begin{array}{c}\text { 99.3\% (Visible light, } \\
90 \text { min) } \\
\text { 92.1\% (Solar light, } \\
120 \text { min) }\end{array}$ & [45] \\
\hline $\mathrm{BC}-\mathrm{TiO}_{2}$ & $\begin{array}{l}\text { Hazelnut shell (HS) } \\
\text { and olive residue } \\
\text { (OR)) }\end{array}$ & Methylene blue (MB) & $\begin{array}{l}\text { Hydrothermal } \\
\text { Sol-gel }\end{array}$ & $\begin{array}{c}{[\mathrm{MB}]=10 \mathrm{ppm}} \\
{[\mathrm{BCPs}]=1 \mathrm{~g} \cdot \mathrm{L}^{-1}} \\
\text { Visible light }\end{array}$ & $\begin{array}{c}96.97 \%\left(\mathrm{HS}-\mathrm{TiO}_{2}\right. \\
420 \mathrm{~min}) \\
82.52 \%\left(\mathrm{OR}-\mathrm{TiO}_{2}\right. \\
420 \mathrm{~min})\end{array}$ & [46] \\
\hline
\end{tabular}


Table 1. Cont

\begin{tabular}{|c|c|c|c|c|c|c|}
\hline BCPs & Biomass & Pollutants & Synthesis Route & Working Conditions & Performance & Refs \\
\hline $\mathrm{BC}-\mathrm{TiO}_{2}$ & Lignin & $\begin{array}{l}\text { Acetaminophen } \\
\text { (ACE) }\end{array}$ & Solvothermal & $\begin{array}{c}{[\mathrm{ACE}]=5 \mathrm{mg} \cdot \mathrm{L}^{-1}} \\
{[\mathrm{BCPs}]=0.25 \mathrm{~g} \cdot \mathrm{L}^{-1}} \\
\text { Solar radiation }\end{array}$ & $92 \%$ (360 min) & [47] \\
\hline $\mathrm{N}-\mathrm{BC}-\mathrm{Bi}_{2} \mathrm{WO}_{6}$ & Pine & $\mathrm{RhB}, \mathrm{Cr}(\mathrm{VI})$ & Solvothermal & $\begin{array}{c}{[\mathrm{RhB}]=10 \mathrm{mg} \cdot \mathrm{L}^{-1}} \\
{[\mathrm{BCPs}]=1 \mathrm{~g} \cdot \mathrm{L}^{-1}} \\
\text { Visible light } \\
{[\mathrm{TC}]=20 \mathrm{mg} \cdot \mathrm{L}^{-1}}\end{array}$ & $\begin{array}{c}99.1 \%(\mathrm{RhB}, 45 \mathrm{~min}) \\
96.7 \%(\mathrm{Cr}(\mathrm{VI}), 30 \mathrm{~min})\end{array}$ & [48] \\
\hline $\mathrm{C} / \mathrm{Fe}_{3} \mathrm{O}_{4} / \mathrm{Bi}_{2} \mathrm{O}_{3}$ & Corn cobs & Tetracycline (TC) & Solvothermal & $\begin{array}{c}{[\mathrm{BCPs}]=1 \mathrm{~g} \cdot \mathrm{L}^{-1}} \\
\text { Visible light }\end{array}$ & $91 \%(90 \mathrm{~min})$ & [38] \\
\hline BC-Zn-Co-LDH & $\begin{array}{l}\text { Wheat husks and } \\
\text { paper sludge }\end{array}$ & Gemifloxacin (GMF) & Hydrothermal & $\begin{array}{c}{[\mathrm{GMF}]=15-35 \mathrm{mg} \cdot \mathrm{L}^{-1}} \\
{[\mathrm{BCPs}]=0.15-0.75 \mathrm{~g} / \mathrm{L}} \\
\text { UV-B light }\end{array}$ & $92.7 \%(130 \mathrm{~min})$ & [49] \\
\hline $\mathrm{BC}-g-\mathrm{MoS}_{2}$ & Rice straw & $\mathrm{TC}$ & $\begin{array}{c}\text { One-pot } \\
\text { hydrothermal }\end{array}$ & $\begin{array}{c}{[\mathrm{TC}]=20 \mathrm{mg} \cdot \mathrm{L}^{-1}} \\
{[\mathrm{BCPs}]=0.4 \mathrm{~g} \cdot \mathrm{L}^{-1}} \\
\text { Visible light } \\
{[\mathrm{MO}]=0.03 \mathrm{mM}}\end{array}$ & $70 \%(240 \mathrm{~min})$ & [50] \\
\hline $\mathrm{BC}-\mathrm{BiOX}(\mathrm{X}=\mathrm{Cl}, \mathrm{Br})$ & Biochar & $\mathrm{MO}$ & One-step hydrolysis & $\begin{array}{c}{[\mathrm{BCPs}]=0.6 \mathrm{~g} \cdot \mathrm{L}^{-1}} \\
\text { Visible light }\end{array}$ & $82 \%(150 \mathrm{~min})$ & [51] \\
\hline $\mathrm{BC}-\mathrm{BiOX}(\mathrm{X}=\mathrm{Cl}, \mathrm{Br})$ & $\begin{array}{l}\text { Sodium } \\
\text { carboxymethyl } \\
\text { cellulose }\end{array}$ & $\mathrm{TC}$ & One-step hydrolysis & $\begin{array}{c}{[\mathrm{TC}]=20 \mathrm{mg} \cdot \mathrm{L}^{-1}} \\
{[\mathrm{BCPs}]=0.25 \mathrm{~g} \cdot \mathrm{L}^{-1}} \\
\text { Visible light }\end{array}$ & $\begin{array}{l}96.5 \%(\mathrm{BiOBr}-\mathrm{BC}), 60 \mathrm{~min} \\
60.3 \% \text { (BiOCl-BC), } 60 \mathrm{~min}\end{array}$ & [52] \\
\hline BC-mp/CdS & Biomass & Rhodamine B (RhB) & $\begin{array}{c}\text { Modified } \\
\text { hydrothermal }\end{array}$ & $\begin{array}{c}{[\mathrm{RhB}]=10 \mathrm{ppm}} \\
{[\mathrm{BCPs}]=0.05 \mathrm{~g} \cdot \mathrm{L}^{-1}} \\
\text { Visible light }\end{array}$ & $K=2.7 \times 10^{-2} \mathrm{~min}^{-1}$ & [53] \\
\hline $\mathrm{BC}-\mathrm{TiO}_{2}$ & $\begin{array}{c}\text { Olive pits (OP) and } \\
\text { wood } \\
\text { shaving (WS) }\end{array}$ & $\mathrm{Cr}(\mathrm{VI})$ & $\begin{array}{c}\text { Ultrasonic-assisted } \\
\text { sol-gel }\end{array}$ & $\begin{array}{c}{[\mathrm{Cr}(\mathrm{VI})]=10 \mathrm{ppm}} \\
{[\mathrm{BCPs}]=0.5 \mathrm{~g} \cdot \mathrm{L}^{-1}} \\
\mathrm{UV} \text { and visible light }\end{array}$ & $\begin{array}{c}100 \% \text { ( } 30 \text { min, } 50 \text { min, } \\
\text { and } 130 \text { min under visible } \\
\text { light for } \mathrm{AC}-\mathrm{TiO}_{2} \\
\mathrm{OP}-\mathrm{TiO}_{2} \text { and } \mathrm{WS}_{-} \mathrm{TiO}_{2} \\
\text { respectively) }\end{array}$ & [40] \\
\hline $\mathrm{BC}-\mathrm{TiO}_{2}$ & $\begin{array}{c}\text { Softwood } \\
\text { Miscanthus straw }\end{array}$ & Phenol & $\begin{array}{l}\text { Ultrasound-promoted } \\
\text { wet impregnation } \\
\text { methodology }\end{array}$ & $\begin{array}{c}{[\text { Phenol }]=50 \mathrm{ppm}} \\
{[\mathrm{BCPs}]=1 \mathrm{~g} \cdot \mathrm{L}^{-1}} \\
\mathrm{UV} \text { and Visible light }\end{array}$ & $\begin{array}{c}\text { 64.1\% (UV light, } 240 \mathrm{~min} \text { ) } \\
33.6 \% \text { (Visible light, } \\
240 \mathrm{~min} \text { ) }\end{array}$ & [41] \\
\hline $\mathrm{BC}-\mathrm{TiO}_{2}$ & Soft Wood Pellets & Phenol & $\begin{array}{l}\text { Ultrasound-assisted } \\
\text { methodology }\end{array}$ & $\begin{array}{c}{[\text { Phenol }]=50 \mathrm{mg} \cdot \mathrm{L}^{-1}} \\
{[\mathrm{BCPs}]=1 \mathrm{~g} \cdot \mathrm{L}^{-1}} \\
\text { UV and Visible light }\end{array}$ & $\begin{array}{c}42.7 \% \text { (UV light, } 240 \mathrm{~min} \text { ) } \\
15.6 \% \text { (Visible light, } \\
240 \mathrm{~min} \text { ) }\end{array}$ & [54] \\
\hline
\end{tabular}


Table 1. Cont

\begin{tabular}{|c|c|c|c|c|c|c|}
\hline BCPs & Biomass & Pollutants & Synthesis Route & Working Conditions & Performance & Refs. \\
\hline $\mathrm{BC}-\mathrm{TiO}_{2} / \mathrm{CuO}$ & Hemp stems & Ammonia & Sonicated method & $\begin{array}{c}\text { [Ammonia] }=100 \mathrm{mg} \cdot \mathrm{L}^{-1} \\
{[\mathrm{BCPs}]=1 \mathrm{~g} \cdot \mathrm{L}^{-1}} \\
\text { UV and Visible light }\end{array}$ & $\begin{array}{l}\text { 99.7\% (UV light) } \\
60.7 \% \text { (Sunlight) }\end{array}$ & [55] \\
\hline $\mathrm{BC}-\mathrm{Fe}_{3} \mathrm{O}_{4} / \mathrm{BiVO}_{4}$ & Pinus roxburghii & Methylparaben (MeP) & Multiple method & $\begin{array}{c}{[\mathrm{MeP}]=5 \mathrm{mg} \cdot \mathrm{L}^{-1}} \\
{[\mathrm{BCPs}]=0.1 \mathrm{~g} \cdot \mathrm{L}^{-1}} \\
\text { Solar radiation } \\
{[\mathrm{IBN}]=20 \mathrm{mg} \cdot \mathrm{L}^{-1}}\end{array}$ & $97.4 \%$ (120 min) & [60] \\
\hline $\begin{array}{c}\mathrm{BC}-\mathrm{g}-\mathrm{C}_{3} \mathrm{~N}_{4} / \\
\text { polyaniline/RGO }\end{array}$ & Bio-waste & $\begin{array}{l}\text { Ibuprofen(IBN) } \\
\text { 2,4-Dichlorophenoxy } \\
\text { acetic acid }(2,4-\mathrm{D})\end{array}$ & $\begin{array}{l}\text { Multi-step thermal } \\
\text { treatment method }\end{array}$ & $\begin{array}{c}{[2,4-\mathrm{D}]=20 \mathrm{mg} \cdot \mathrm{L}^{-1}} \\
{[\mathrm{BCPs}]=0.5 \mathrm{~g} \cdot \mathrm{L}^{-1}} \\
\text { Visible light and Natural } \\
\text { sunlight }\end{array}$ & $\begin{array}{l}99.7 \%(2,4-\mathrm{D}, 90 \mathrm{~min}) \\
98.4 \% \text { (IBN, } 90 \mathrm{~min})\end{array}$ & [61] \\
\hline $\mathrm{BC}-\mathrm{TiO}_{2}$ & Softwood/Lignin & Phenol & $\begin{array}{c}\text { Mechanical } \\
\text { mixing/pyrolysis }\end{array}$ & $\begin{array}{c}{[\text { Phenol }]=50 \mathrm{mg} \cdot \mathrm{L}^{-1}} \\
{[\mathrm{BCPs}]=1 \mathrm{~g} \cdot \mathrm{L}^{-1}} \\
\text { UV light }\end{array}$ & $\begin{array}{c}52.5 \%\left(\mathrm{TiO}_{2}-\mathrm{SWP700}\right. \\
240 \mathrm{~min}) \\
35.8 \%\left(\mathrm{TiO}_{2}-\mathrm{LIGNIN},\right. \\
240 \mathrm{~min})\end{array}$ & [62] \\
\hline $\mathrm{BC}-\mathrm{TiO}_{2}$ & Bamboo & MB & Calcination & $\begin{array}{c}{[\mathrm{MB}]=12.8 \mathrm{mg} \cdot \mathrm{L}^{-1}} \\
{[\mathrm{BCPs}]=0.2 \mathrm{~g} \cdot \mathrm{L}^{-1}} \\
\mathrm{UV} \text { and Visible light }\end{array}$ & $97 \%(60 \mathrm{~min})$ & [34] \\
\hline BC-CdS & Lotus-leaf & $\mathrm{RhB}, \mathrm{MO}, \mathrm{MB}$ & Calcination & $\begin{array}{c}\text { [Dye }]=40 \mathrm{mg} \cdot \mathrm{L}^{-1} \\
{[\mathrm{BCPs}]=0.1 \mathrm{~g} \cdot \mathrm{L}^{-1}} \\
\text { Visible light }\end{array}$ & $\begin{array}{c}97.8 \%(\mathrm{MO}, 60 \mathrm{~min}) \\
96.3 \%(\mathrm{MB}, 150 \mathrm{~min})\end{array}$ & [56] \\
\hline BC-g- $\mathrm{C}_{3} \mathrm{~N}_{4}$ & $\begin{array}{l}\text { Camellia oleifera } \\
\text { shells }\end{array}$ & $\mathrm{Cr}(\mathrm{VI})$ & Calcination & $\begin{array}{c}{[\mathrm{Cr}(\mathrm{VI})]=10 \mathrm{mg} \cdot \mathrm{L}^{-1}} \\
{[\mathrm{BCPs}]=0.2 \mathrm{~g} \cdot \mathrm{L}^{-1}} \\
\text { Visible light }\end{array}$ & $100 \%$ (240 min) & [57] \\
\hline $\mathrm{BC}-\mathrm{ZnO}$ & $\begin{array}{c}\text { Corn cob (CC) } \\
\text { Red mombin seed } \\
\text { (RMS) }\end{array}$ & MB & Calcination & $\begin{array}{c}{[\mathrm{MB}]=10 \mathrm{mg} \cdot \mathrm{L}^{-1}} \\
{[\mathrm{BCPs}]=0.1,0.2,0.5 \mathrm{~g} \cdot \mathrm{L}^{-1}} \\
\text { UV light }\end{array}$ & $\begin{array}{c}K_{1}=0.09 \mathrm{~min}^{-1} \\
(\mathrm{CC}-\mathrm{ZnO}, 300 \mathrm{~min}) \\
K_{1}=0.06 \mathrm{~min}^{-1} \\
(\mathrm{RMS}-\mathrm{ZnO}, 300 \mathrm{~min})\end{array}$ & [58] \\
\hline $\mathrm{BC}-\mathrm{CoFe}_{2} \mathrm{O}_{4} / \mathrm{Ag}_{3} \mathrm{PO}_{4}$ & Pine pollen & Bisphenol A (BPA) & In situ precipitation & $\begin{array}{c}{[\mathrm{BPA}]=20 \mathrm{mg} \cdot \mathrm{L}^{-1}} \\
{[\mathrm{BCPs}]=0.5 \mathrm{~g} \cdot \mathrm{L}^{-1}} \\
\text { Visible light }\end{array}$ & $\begin{array}{c}91.12 \% \text { (Remove } \\
\text { efficiency, } 60 \mathrm{~min} \text { ) } \\
80.23 \% \text { (Mineralization, } \\
60 \mathrm{~min} \text { ) }\end{array}$ & [59] \\
\hline BC-CdSe & Bamboo & $\mathrm{TC}$ & In situ method & $\begin{array}{c}{[\mathrm{TC}]=20 \mathrm{mg} \cdot \mathrm{L}^{-1}} \\
{[\mathrm{BCPs}]=0.5 \mathrm{~g} \cdot \mathrm{L}^{-1}} \\
\text { Visible light }\end{array}$ & $73 \%$ (80 min) & [35] \\
\hline
\end{tabular}


Table 1. Cont

\begin{tabular}{|c|c|c|c|c|c|c|}
\hline BCPs & Biomass & Pollutants & Synthesis Route & Working Conditions & Performance & Refs. \\
\hline $\mathrm{BC}-\mathrm{g}-\mathrm{C}_{3} \mathrm{~N}_{4} / \mathrm{FeVO} 4$ & Pinus roxburrghii & $\begin{array}{c}\text { Methyl paraben } \\
\text { (MeP), } \\
\text { 2-chlorophenol (2-CP) }\end{array}$ & $\begin{array}{l}\text { Multi-step (thermal } \\
\text { treatment, acid } \\
\text { treatment, and } \\
\text { ammonia treatment) }\end{array}$ & $\begin{array}{c}{[\mathrm{MeP} / 2-\mathrm{CP}]=20 \mathrm{mg} \cdot \mathrm{L}^{-1}} \\
{[\mathrm{BCPs}]=0.5 \mathrm{~g} \cdot \mathrm{L}^{-1}} \\
\text { Sunlight }\end{array}$ & $\begin{array}{l}\text { TOC removal rate: } \\
74.2 \%(\mathrm{MeP}, 60 \mathrm{~min}) \\
73.9 \%(2-\mathrm{CP}, 60 \mathrm{~min})\end{array}$ & [37] \\
\hline $\mathrm{BC}-\mathrm{TiO}_{2}$ & Macroalgae & $\begin{array}{l}\text { Simulated textile } \\
\text { wastewater (TW) }\end{array}$ & Wet precipitation & $\begin{array}{c}{[\mathrm{TW}]=5 \mathrm{mg} \cdot \mathrm{L}^{-1}} \\
{[\mathrm{BCPs}]=2 \mathrm{~g} \cdot \mathrm{L}^{-1}} \\
\text { Visible light }\end{array}$ & $99.20 \%(180 \mathrm{~min})$ & [63] \\
\hline $\mathrm{BC}-\mathrm{Bi} / \mathrm{Bi}_{2} \mathrm{O}_{3}$ & Rice straws (RS) & Estrone & Impregnation & $\begin{array}{c}\text { [Estrone] }=2.8 \mathrm{mg} \cdot \mathrm{L}^{-1} \\
{[\mathrm{BCPs}]=1 \mathrm{~g} \cdot \mathrm{L}^{-1}} \\
\text { UV and Visible light }\end{array}$ & $\begin{aligned} K_{\mathrm{obs}}= & 0.045 \mathrm{~min}^{-1} \\
& (60 \mathrm{~min})\end{aligned}$ & [64] \\
\hline
\end{tabular}




\subsection{Sol-gel Method}

The sol-gel method is relatively simple, and the prepared nanomaterials have high purity and uniform particle size. Generally, the sol is prepared by uniformly mixing the sol and the carbon materials, followed by ageing to form a gel and calcination at a higher temperature. However, the main disadvantage of this method is the shape of the material is not well controlled.

Recently, Zhang et al. [28] fabricated BC(coconut shell)- $\mathrm{TiO}_{2}$ compound by sol-gel method. First, the coconut shell was pyrolyzed under nitrogen, followed by washing and rinsing with $\mathrm{HCl}$ acid. Secondly, the acid-treated biochar was ageing, washed, dried overnight, and sieved through the mesh. Then, the sol-gel process involved the following sequences. (1) Mixed ethanol with butyl titanate to form solution A; (2) solution B was obtained through mixing ethanol, deionized water, acetic acid with polyethylene glycol; (3) dropwise added solution B into solution A and aged for $24 \mathrm{~h}$. Then, the as-prepared BC was mixed with the sol-gel. Finally, the above mixture was further treated by ageing, filtration, drying, and calcination to form the BCPs. The scheme of the BCPs synthetic process was illustrated in Figure 2A.

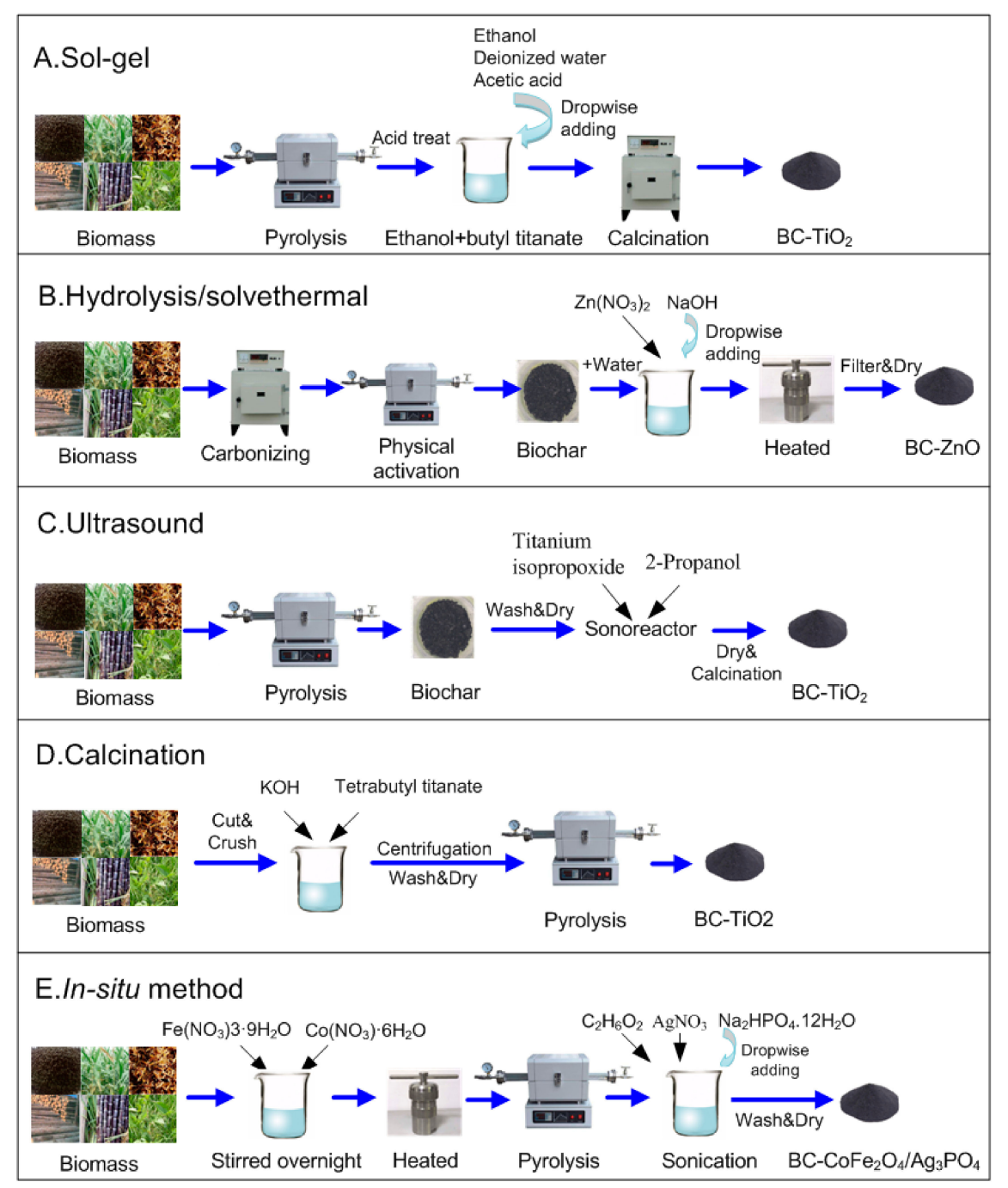

Figure 2. Schematic image of the preparation methods of BCPs.

For comparison, Silvestri et al. [29] impregnated $\mathrm{TiO}_{2}$ in the Salvinia molesta derived carbonaceous matrices via the sol-gel process and mechanical mixing route. The results showed that the type of $\mathrm{TiO}_{2}$ precursor plays a much more critical role than the impregnation method on the photocatalytic 
efficiency of the composites. Compared with the sol-gel way, the BCPs fabricated by mechanical mixing exhibited higher photocatalytic performance.

\subsection{Hydrothermal/Solvothermal Method}

Hydrothermal/solvothermal method is a crystallization process at relatively low reaction temperature $\left(<20{ }^{\circ} \mathrm{C}\right)$ and higher pressure. It has gained plenty of successes for its outstanding advantages of low agglomeration, better product purity, higher dispersion and low cost in energy [65]. Different kinds of BCPs can be attained by the hydrothermal/solvothermal technique [36,45-53].

Vinayagam et al. [36] synthesized $\mathrm{ZnO} / \mathrm{BC}$ composite by hydrothermal method (shown in Figure 2B). In a typical synthesis, waste biomass was washed and dried, followed by carbonizing under $500-600^{\circ} \mathrm{C}$. Then, the obtained material was activated via physical activation method under an inert atmosphere. Different weight ratios of BCPs were prepared. First, zinc nitrate and BC were mixed and stirred in distilled water, followed by dropwise adding $\mathrm{NaOH}(1 \mathrm{M})$ till the $\mathrm{pH}$ was 10 . Then, the suspension was heated for $6 \mathrm{~h}$ at $120^{\circ} \mathrm{C}$. Later, the obtained material was centrifuged, washed, and dried overnight. The result showed $\mathrm{ZnO}$ exhibited reduced band gap energy, excellent activities, and reusability either under UV or visible-light irradiations by combined with $\mathrm{BC}$.

In another study, Peñas-Garzón et al. [47] prepared $\mathrm{TiO}_{2} / \mathrm{BC}$ composite for photocatalytic degradation of acetaminophen under solar light via a multi-step solvothermal process. First, the biomass (lignin) was activated by using different agents. Then, the $\mathrm{BC}$ was suspended into the $\mathrm{EtOH}$ at room temperature to form solution A. Meanwhile, $\mathrm{Ti}(\mathrm{OBu})_{4}$ was diluted into EtOH (solution $\mathrm{B}$ ). Later, solution B was dropwise added to solution A until complete homogenization. Afterwards, the hydrolysis of the Ti precursor was performed by adding dropwise water. The mixture was stirred and heated, followed by separation, washing, and drying overnight to obtain $\mathrm{TiO}_{2} / \mathrm{BC}$. Through hydrothermal/solvothermal route, anatase phase with an average grain size of $10 \mathrm{~nm}$ was formed. $\mathrm{TiO}_{2}-\mathrm{BC}$ displayed much higher activities than bare $\mathrm{TiO}_{2}$ for the removal of acetaminophen under solar light.

\subsection{Ultrasound Method}

Ultrasound method has rapidly attracted considerable attention in recent years. As a green technology, this procedure has excellent potential for photocatalysts fabrication, owing to the low temperature, atmospheric pressure, and instant reaction. The obtained photocatalyst exhibited purity phase, high surface area, uniform particle coatings, and different particle sizes and shapes. Moreover, the parameters can be easily adjusted in the preparation process [66]. Lisowski's group $[41,54,66]$ have developed a series of $\mathrm{TiO}_{2}$-BCPs derived from biomass via a novel ultrasound-assisted methodology. The typical preparation procedure was as follows (Figure 2C). Biochar was prepared via pyrolysis of softwood pellets and miscanthus straw pellets. Then, the as-fabricated BC was mixed with titanium isopropoxide and 2-Propanol, followed by sonication for $1 \mathrm{~h}$. Later, the solvent was removed using a rotary vacuum evaporator assisted by sonication. Subsequently, the obtained mixture was dried and calcined at $400{ }^{\circ} \mathrm{C}$ in static air to obtain BCPs. The authors demonstrated that ultrasound could promote the formation of $\mathrm{C}-\mathrm{C} \mathrm{sp}{ }^{2}$ and $\mathrm{sp}^{3}, \mathrm{C}-\mathrm{O}-\mathrm{C}, \mathrm{COOH}, \mathrm{O}=\mathrm{CO}$ and $\mathrm{C}=\mathrm{C}-\mathrm{OH}$, which may lead to the evolution of surface oxygen vacancies and $\mathrm{Ti}^{3+}$ defects.

\subsection{Calcination}

Wang et al. [34] fabricated bamboo char- $\mathrm{TiO}_{2}$ composites by calcination route. The schematic for the calcination process is given in Figure 2D. Typically, the bamboo was cut and crushed into powder with different sizes. Then, the bamboo power and tetrabutyl titanate were added into the potassium hydroxide $(\mathrm{KOH})$ solution and kept stirring, followed by centrifugation, washing and drying. Afterwards, the obtained precursors were calcinated at $800{ }^{\circ} \mathrm{C}$ under inert gas. They suggested that through the calcination method, the crystallinity of the BCPs was enhanced (93.2\%), compared 
with that of precursor (78.3\%). The BCPs improved the photocatalytic activity under both visible-light irritation and UV region.

In another research, biochar (camellia oleifera shells) coupled g- $\mathrm{C}_{3} \mathrm{~N}_{4}$ nanosheets composites were prepared by a two-step calcination method by $\mathrm{Li}$ et al. [60]. They found that the double calcination process can promote the removal of the small $\mathrm{g}-\mathrm{C}_{3} \mathrm{~N}_{4}$. Moreover, owing to the synergistic effects, the $\mathrm{BCPs}$ displayed remarkable stability for 4-FP degradation.

\subsection{In-Situ Method}

Carbon doped anatase $\mathrm{TiO}_{2}$ spheres can be prepared via an in situ method, which was considered to avoid the aggregation of carbon species arises in external carbon precursors addition. Furthermore, carbon can dope in the place of oxygen in the $\mathrm{TiO}_{2}$ lattice [4]. Some researchers $[35,62,63,67]$ have reported the synthesis of BCPs using the in situ method. Brandes et al. [67] proposed an in situ approach to insert $\mathrm{TiO}_{2}$ in the bacterial cellulose matrix. Typically, bacterial cellulose hydrogel was suspended in $\mathrm{H}_{2} \mathrm{SO}_{4}$ solution $(65 \%)$, followed by dropwise addition of $\mathrm{TiOSO}_{4} \cdot \mathrm{H}_{2} \mathrm{SO}_{4} \cdot \mathrm{H}_{2} \mathrm{O}$ and constant stirring. Then, the mixture was filtered, washed, and dried under vacuum to obtain the BCPs. The ex situ method was also employed for comparison. Spherical bacterial cellulose hydrogels were mixed with P25 and deionized water, forming a sol-gel solution. Afterwards, the as-fabricated mixture was stirred, separated, and washed to remove the residues for further use. They found that the MB removal rate of $70.83 \%$ and $89.58 \%$ were achieved, through in situ and ex situ route, respectively.

Very recently, Zhai et al. [62] synthesized BCPs via an in situ precipitation method (Figure 2E). The magnetic BC@CoFe ${ }_{2} \mathrm{O}_{4}$ was fabricated by a one-pot method. Pine pollen was mixed with $\mathrm{Fe}\left(\mathrm{NO}_{3}\right)_{3} \cdot 9 \mathrm{H}_{2} \mathrm{O}$ and $\mathrm{Co}\left(\mathrm{NO}_{3}\right) \cdot 6 \mathrm{H}_{2} \mathrm{O}$ and stirred overnight, followed by $\mathrm{pH}$ adjusting till 12 with $\mathrm{NaOH}$ and stirring another $1 \mathrm{~h}$. Then, the obtained solution was heated at $180{ }^{\circ} \mathrm{C}$ for $12 \mathrm{~h}$. Later, the as-prepared powder was pyrolyzed at $500{ }^{\circ} \mathrm{C}$ under nitrogen atmosphere to obtain the magnetic biochar (BC@CoFe $\mathrm{O}_{4}$ ). BC@ $@ \mathrm{CoFe}_{2} \mathrm{O}_{4} / \mathrm{Ag}_{3} \mathrm{PO}_{4}$ was further synthesized via the in situ precipitation method. BC@CoFe ${ }_{2} \mathrm{O}_{4}$ were added to $\mathrm{C}_{2} \mathrm{H}_{6} \mathrm{O}_{2}$ and sonicated for $30 \mathrm{~min}$, followed by adding $50 \mathrm{~mL}$ $\mathrm{AgNO}_{3}$. Then, $50 \mathrm{~mL} \mathrm{Na} \mathrm{HPO}_{4} \cdot 12 \mathrm{H}_{2} \mathrm{O}$ was dropwise added to the above mixture and kept stirring. Later, the as-prepared mixture was washed and collected for further use. They demonstrated that the increased photocatalytic performance for bisphenol A removal was owing to the in situ process.

\section{Characterization}

Various characterization methods have been carried out to evaluate the physical, chemical, and mechanical properties of $\mathrm{BC}$ and BCPs, such as scanning electron micros copy (SEM), scanning electron microscopy-energy dispersive $X$-ray spectrometry (SEM-EDS), transmission electron microscopy (TEM), X-ray diffraction (XRD), Fourier transform infrared (FT-IR), Raman spectroscopy, X-ray photoelectron spectroscopy (XPS) and solid-state nuclear magnetic resonance (NMR), etc. (Figure 3).

\subsection{Morphology and Surface Area}

SEM provides information regarding the structure and microscopic features of BC and BCPs. The sizes of the pores in the $\mathrm{BC}$ may be different extremely as the pyrolysis temperature increased. For example, the $\mathrm{BC}$ present honeycomb-like pores at a pyrolysis temperature of $700{ }^{\circ} \mathrm{C}$ while it disappeared at $200^{\circ} \mathrm{C}$ [68]. However, the hollow structure of $\mathrm{BC}$ may be broken when the pyrolysis temperature increased to $700^{\circ} \mathrm{C}$ [55]. TEM is exceptional for its quality to identify the morphology, crystallinity, and structure of BC and BCPs. Abdul et al. [69] found that graphene nanosheets were transparent and slightly aggregated within $\mathrm{BC}$ through the TEM images. Xiao et al. [70] observed the multi-layered structures and nanocrystalline structures of $\mathrm{BC}$. 


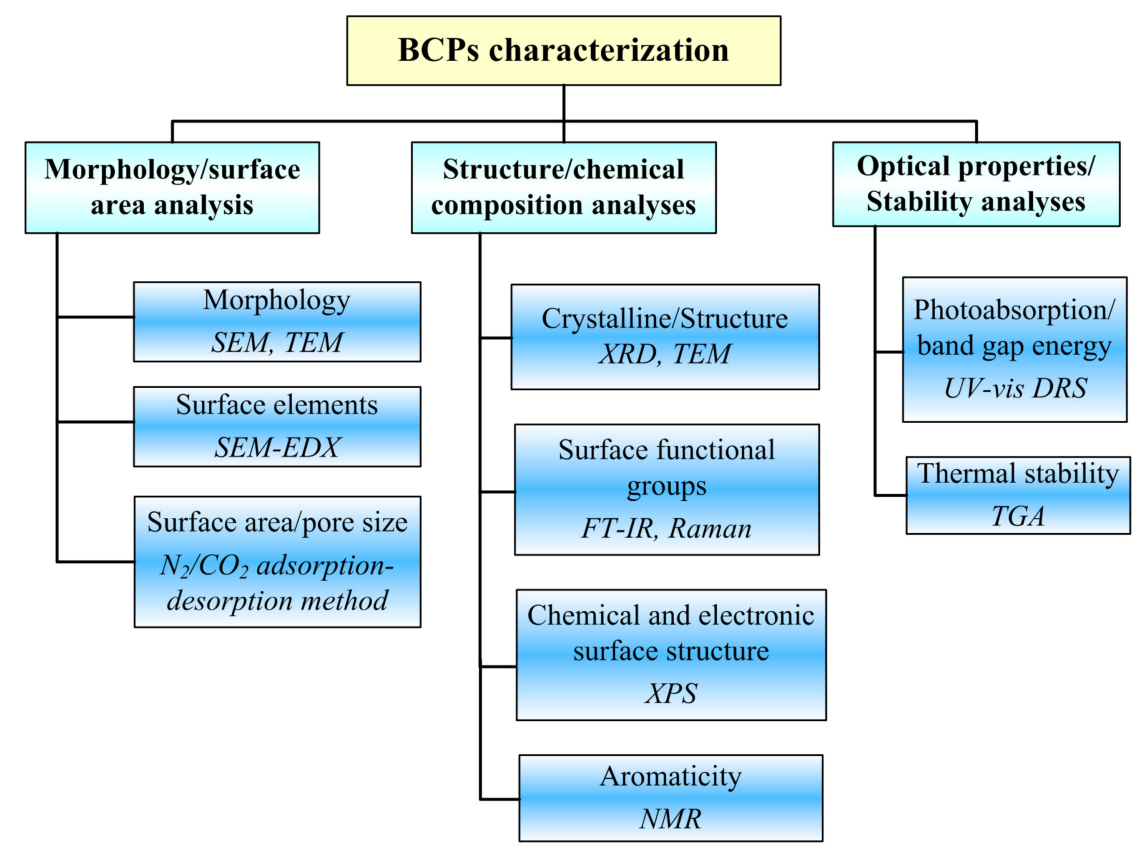

Figure 3. Graphical overview of BC and BCPs characterization.

SEM-EDS is widely applied to identify and quantify the elements in BC. For instance, it was observed that the predominant elements in the sludge-derived BC samples were carbon, oxygen, silica, aluminum, calcium, sulfur, phosphorus, and potassium, etc. [71]. Zhao et al. [68] used SEM-EDS to analyze the elements in the rapeseed stem biochar. They demonstrated the $C$ content increased, and the $\mathrm{O}$ content decreased as the pyrolysis temperature rose.

The specific surface areas $\left(\mathrm{S}_{\mathrm{BET}}\right)$ and porosity properties of the $\mathrm{BC}$ and $\mathrm{BCPs}$ could be investigated by $\mathrm{N}_{2}$ adsorption-desorption isotherm. Generally, the large specific surface area facilitates the adsorption of pollutants. In most cases, after the combination, the $\mathrm{S}_{\mathrm{BET}}$ of the BCPs is higher than that of the original $\mathrm{BC}$. However, it was found that the mesopores and micropores of $\mathrm{BC}$ may be clogged due to the aggregation of semiconductors, thus inducing the decrease of the $S_{B E T}[62,72]$.

\subsection{Structure and Chemical Composition}

XRD is frequently applied to examine the crystalline structure and phase of BC and BCPs. Ye et al. [50] compared the XRD spectrum before and after catalytic degradation. They found that the crystal structure of the g-MoS $/ \mathrm{PGBC}$ remains unchanged. Fazal et al. [63] used XRD to investigate the $\mathrm{BC}$ (macroalgae) and $\mathrm{BC}-\mathrm{TiO}_{2}$ composite. XRD spectra showed that the peak located at $26.9^{\circ}$ and $43^{\circ}$ corresponded to the (002) plane of crystalline carbon, associating with the graphite-like structures. Furthermore, the graphitic peaks declined with the increase of $\mathrm{TiO}_{2}$ loading, indicating the good intercalation of $\mathrm{TiO}_{2}$ nanoparticles between $\mathrm{BC}$ layers.

FT-IR spectra can be applied to distinguish the functional groups and the degree of carbonization of $\mathrm{BC}$. The band absorbance at $710 \mathrm{~cm}^{-1}$ was a characteristic feature of $\mathrm{BC}$ [63]. The peak between $875-1035 \mathrm{~cm}^{-1}$ was associated with $\mathrm{C}-\mathrm{O}$ and $\mathrm{OH}-$ stretching vibration. The absorption band was found to shift to higher wavenumber with the increase of $\mathrm{TiO}_{2}$, which indicated that the $\mathrm{T}-\mathrm{OC}-$ bond changed the optical property and charge transfer. Geng et al. [73] used FT-IR spectra to investigate the molecular component and the degree of carbonization of $\mathrm{BC}$ (cellulose). The peaks at 3450, 1750, 1635 and $1040 \mathrm{~cm}^{-1}$ can be assigned to the stretching vibration of the $-\mathrm{OH}, \mathrm{C}=\mathrm{O}$ and $\mathrm{C}-\mathrm{O}-\mathrm{C}$, respectively. It was stated that the cellulose skeleton was converted to the graphitic structure of amorphous carbon nanofibers during the pyrolysis process.

XPS measurement is applied to analyze the composition and surface chemistry of BC and BCPs. More functional groups of $\mathrm{BC}$ at binding energies of $291.2 \mathrm{eV}$ and $531.8 \mathrm{eV}$ associated with carbonates 
and $\mathrm{C}=\mathrm{O}$ were observed than in the case of pure lignin [62]. It was found that the pyrolysis process can cause an increase in the surface activity of carbon functional groups present on the surface of BC. Moreover, binding energies of $284.8 \mathrm{eV}$ and $288.6 \mathrm{eV}$ were due to the adventitious elemental carbon and $\mathrm{C}-\mathrm{O}$ bonds, respectively, indicating the presence of Ti-O-C structure [74].

Raman spectroscopy can be used to characterize BC-based nanostructures. Al-Kahtani et al. [75] demonstrated the $D$ band at $1351 \mathrm{~cm}^{-1}$ and $\mathrm{G}$ band at $1587 \mathrm{~cm}^{-1}$ was characteristic bands of graphite carbon. The intensity ratio $\left(\mathrm{I}_{\mathrm{D}} / \mathrm{I}_{\mathrm{G}}\right)$ reflected the crystalline and graphitization of $\mathrm{BC}[38]$. The $\mathrm{I}_{\mathrm{D}} / \mathrm{I}_{\mathrm{G}}$ value of $\mathrm{C} / \mathrm{Fe}_{3} \mathrm{O}_{4} / \mathrm{Bi}_{2} \mathrm{O}_{3}$ and $\mathrm{C} / \mathrm{Fe}_{3} \mathrm{O}_{4}$ were 0.84 and 0.82 , respectively, indicating that the graphitization of $\mathrm{BC}$ made the $\mathrm{BCPs}$ from disorder to order, which was beneficial for electronic conduction. Lower $\mathrm{I}_{\mathrm{D}} / \mathrm{I}_{\mathrm{G}}$ means higher graphitization. The BCPs fabricated via ultrasound route displayed a slightly lower $\mathrm{I}_{\mathrm{D}} / \mathrm{I}_{\mathrm{G}}$ value (0.37) compared to pure $\mathrm{BC}(0.48)$. It was stated the slight change of graphitization might be caused by the reconstruction of structural defects within the $\mathrm{sp}^{2}$ carbon network that arose upon the ultrasound-assisted synthesis method [41].

NMR is another spectroscopic technique commonly used to in-depth investigate the fine structure of BC. The degree of carbonization and stability of BC pyrolyzed at different temperatures and heating rates can be compared using the NMR spectroscopy $[76,77]$. Moreover, it can provide details on the functional groups and hydrocarbons [78]. Moreover, it was considered that NMR was more suitable for analyzing BC containing C compounds than functional groups [79]. Hence, researchers commonly used both NMR and FT-IR to examine the structure and functional groups.

\subsection{Optical Property and Stability}

UV-vis diffuse reflectance spectroscopy (DRS) is commonly applied to investigate the optical properties and energy band features of BCPs. Carbon can expand the absorbance range to the visible region [74]. The BCPs showed a red-shift toward longer wavelengths when semiconductors were combined with $B C$ to form the composites $[40,41]$. However, the absorbance was relatively weak in the visible region because of the low content of $\mathrm{BC}$ [43]. The band gap energy of BCPs can be calculated by application of the Kubelka-Munk function [36,80]. The BCPs displayed much different photocatalytic performance in terms of the difference in band gap energy values [41].

Thermogravimetric analysis (TGA) is performed to assess the mass loss and relative stability of BC. Xiong et al. [81] applied TGA to analyze the thermal stability of sulfonated BC. The derivative thermogravimetric (DTG) peak at $600-700{ }^{\circ} \mathrm{C}$ diminished while the peak at $200-300{ }^{\circ} \mathrm{C}$ became predominant after the sulfonation process. At $1000^{\circ} \mathrm{C}$, the TGA spectra exhibited a more significant mass loss of sulfonated BC (20 wt.\%), in comparison with raw BC (16 wt.\%), indicating that sulfonation inevitably weakened the thermal stability of BC.

\section{Mechanism}

Semiconductors have been widely studied for its high thermal and chemical stability, strong oxidizing ability and low cost. Owing to the relatively wide band gap energy $(3.20 \mathrm{eV})$ and low quantum efficiency, $\mathrm{TiO}_{2}$ can only respond in the ultraviolet light, which occupies only about $5 \%$ of the sunlight spectrum. Therefore, the development of photocatalysts for absorbing visible light is highly required. The participation of biochar in the synthesis process can change the structure, morphology and light absorption efficiency of the composites, leading to an enhanced performance. The functional groups existed in the biochar may also play pivotal roles in the reaction and further promote the photocatalytic ability [52]. Contaminants in wastewater can be removed based on different mechanisms, which involve: adsorption ability, narrowing the band gap, facilitating the electron transport, suppression of electron/hole charges recombination, $\pi-\pi$ stacking interactions, electrostatic interaction, reducing the photocorrosion of $\mathrm{TiO}_{2}$, etc. The main mechanisms are summarized below. 


\subsection{Adsorption}

Owing to its large surface areas, structure stability, and low cost, BC has been frequently applied as support to disperse catalyst nanoparticles. Impregnation of foreign materials onto BC can remove various contaminants through simultaneous adsorption and degradation. In this integrated technology, the adsorption process can enrich pollutants to facilitate the degradation process, as free radicals are very short lived [82]. Kumar et al. [60] concluded that the adsorbed contaminants were more prone to attack by radicals. As soon as the methylparaben was adsorbed onto the surface of BC, it got degraded. Ye et al. [50] explored the removal of tetracycline hydrochloride was dependent on adsorption and degradation processes. They found the BCPs displayed comparatively large adsorbed ability, which was enhanced with increasing BC content. Moreover, the BCPs exhibited a better adsorption effect but weak photocatalytic degradation performance, owing to the poor electron conductivity of the inactivated $\mathrm{BC}$ and the serious stacking of $\mathrm{MoS}_{2}$. $\mathrm{BC}$ can be used as support structure for adsorption molecules and as potent substrate for the growth of $\mathrm{TiO}_{2}$ photocatalyst on its functionalized surface [63].

\subsection{Narrowing the Band Gap}

Combining $\mathrm{TiO}_{2}$ with carbonaceous nanomaterials may result in the band gap narrowing. Some ways were summarized below.

(i) Ti-O-C bonding bridge. Di Valentin et al. [83] investigated that carbon can act as a dopant to replace $\mathrm{O}$ and Ti by using density functional theory (DFT) calculations. The calculated structures suggested it was easier to replace $\mathrm{O}$ when the amount of doped carbon is low and in the oxygen-poor environment, whereas, under oxygen-rich condition, substitution to Ti is preferred. The chemically bonded Ti-O-C plays a significant role in narrowing the band gap, thus promoting the photocatalytic ability [84-86]. The spectral response range can be broadened to the visible region due to the forming of Ti-O-C bonds $[87,88]$. Djellabi et al. [89] synthesized $\mathrm{TiO}_{2}$-olive pits lignocellulosic biochar photocatalysts via ultrasonic-assisted sol-gel method. $\mathrm{TiO}_{2}$ clusters were successfully bonded to $\mathrm{BC}$ functional groups through Ti-O-C bridge (Figure 4A). The Ti-O-C was more pronounced in the samples of lower BC content, while the light absorbance increased with the BC content. Additionally, the optical absorption edge of $\mathrm{TiO}_{2}$ was shifted towards the visible-light region due to the introduction of $\mathrm{BC}$. Ti-O-C bonds exhibited a remarkable role in band gap narrowing. The band gap energy varied from 3.02 to $2.63 \mathrm{eV}$ depending on the $\mathrm{TiO}_{2} / \mathrm{BC}$ ratio.

$A$

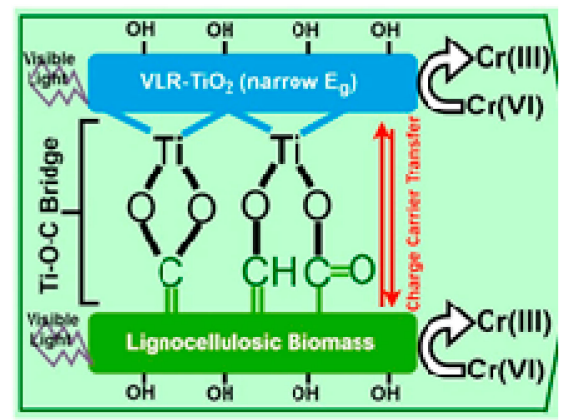

(a)

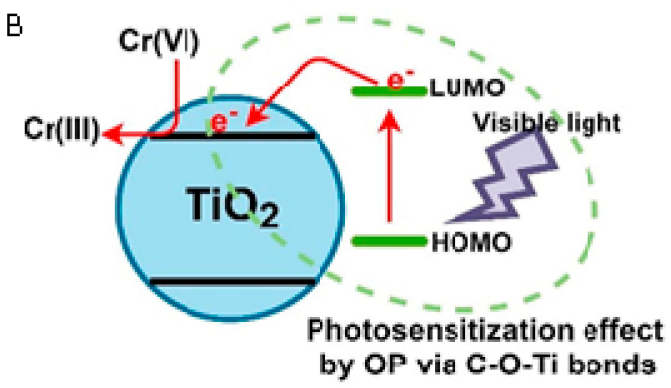

(b)

Figure 4. Schematic illustration of the proposed mechanism of narrowing the band gap induced by C-O-Ti bond (A) and photosensitization (B). Reproduced with permission from reference [89].

(ii) Carbonaceous materials can act as photosensitizers and charges receiver to narrow the band gap when combined with other semiconductors [89,90]. Djellabi et al. [89] demonstrated that the BC displayed an organic structure, which induced the visible-light absorption. The photosensitization of $\mathrm{TiO}_{2}$ by BC polymer is shown in Figure 4B. Although the BCPs with higher biochar content showed an 
obvious visible-light response and narrow band gap, the photocatalytic reduction rate of $\mathrm{Cr}(\mathrm{VI})$ was the lowest. It was because the higher content of biochar may block the light absorption and affect the electrons generating. Peng et al. [55] reported similar photosensitization effects by BCPs.

\subsection{Facilitating the Electron Transport}

By introducing of biochar, the separation efficiency of electron-holes is enhanced due to the excellent electron transmission ability [91], thus significantly improved charge transport properties. Meng et al. [92] stated that the $\pi$-conjugated electron systems from BC was an efficient electronic transfer. The $\mathrm{h}^{+}$migrates to the surface of $\mathrm{TiO}_{2}$ and produce $\cdot \mathrm{OH}$, which prolonged the separation lifetime of $\mathrm{e}^{-}$ and $\mathrm{h}^{+}$[30]. BC modified Z-scheme heterojunction was constructed via a facile method [93] (Figure 5). The BCPs showed excellent photocatalytic activity of tetracycline (TC) and $\mathrm{Cr}(\mathrm{VI})$, recyclability and stability. $\mathrm{O}_{2}{ }^{-}, \cdot \mathrm{OH}$ and $\mathrm{h}^{+}$generated in the photodegradation process were proved to be the important active species. Much higher $\cdot \mathrm{O}_{2}^{-}$generated in BCPs mainly attributed to the electrons transferred from the conduction band of $\mathrm{g}-\mathrm{C}_{3} \mathrm{~N}_{4}$ to the surface of $\mathrm{BC}$. BC decorated Z-scheme system effectively facilitated the interfacial charge separation and transfer (Figure 3). Li et al. [51] prepared BC/BiOX $(\mathrm{X}=\mathrm{Cl}, \mathrm{Br}$ ) composites for MO removal. Similarly, they found that as a carbon dopant, the $\mathrm{BC}$ can facilitate the charge separation of the BCPs and elevate the photocatalytic performance under visible light.

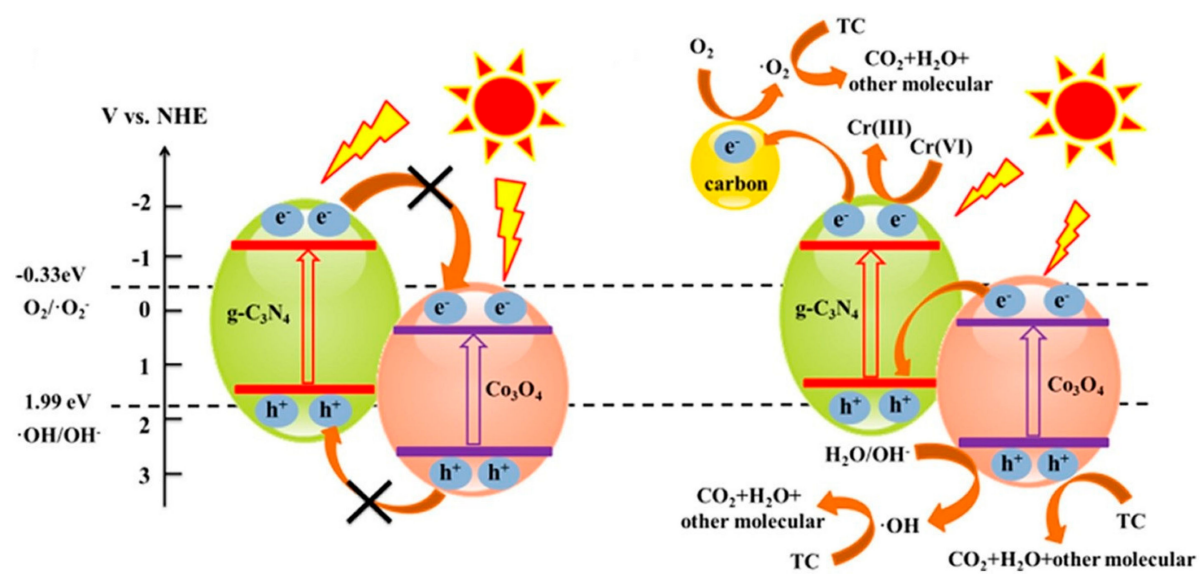

Figure 5. Schematic illustration of the proposed mechanism for facilitating electron transport. Reproduced with permission from reference [93].

\subsection{Suppression of Electron-hole Recombination}

The lifetime of photogenerated carriers affects photocatalysis significantly. The trapped $\mathrm{e}^{-}$and $\mathrm{h}^{+}$transferred immediately to the surface and reacted with adsorbed oxygen and water molecules to generate free radicals. However, the lifetime is generally nanosecond, and the electron-hole pairs recombine instantly and induce deactivation.

Carbonaceous materials enhance the electrons-holes separation owing to the excellent double conductivity. Peng et al. [55] prepared $\mathrm{TiO}_{2}-\mathrm{CuO} / \mathrm{BC}$ (hemp stem) under different calcination temperature $\left(500,600\right.$ and $\left.700^{\circ} \mathrm{C}\right)$. They found the enhanced removal of ammonia was owing to the retardation of $\mathrm{e}^{-} / \mathrm{h}^{+}$pairs. Moreover, the $\mathrm{BC}$ formed a mid-gap energy state above the $\mathrm{VB}$ of $\mathrm{TiO}_{2}$ (Figure 6A). Gao et al. [38] synthesized $\mathrm{BC} / \mathrm{Fe}_{3} \mathrm{O}_{4} / \mathrm{Bi}_{2} \mathrm{O}_{3}$ composite via a solvothermal method. The electrons in $\mathrm{Bi}_{2} \mathrm{O}_{3}$ were transported to the $\mathrm{BC} / \mathrm{Fe}_{3} \mathrm{O}_{4}$, thus inhibiting the recombination of $\mathrm{h}^{+}$and $\mathrm{e}^{-}$ pairs. The magnetic nanoparticles $\left(\mathrm{BC} / \mathrm{Fe}_{3} \mathrm{O}_{4}\right)$ acted as an electron storage center, which was beneficial to transfer the electron from $\mathrm{Bi}_{2} \mathrm{O}_{3}$ and reduce the probability of electron return to $\mathrm{Bi}_{2} \mathrm{O}_{3}$ (Figure $6 \mathrm{~B}$ ). Meng et al. [92] suggested the synergistic effect between biochar and g- $\mathrm{C}_{3} \mathrm{~N}_{4}$ resulted in a longer lifetime of excited electrons of semiconductor and hindered photo-induced electron-hole recombination. Fazal et al. [63] also found that photodegradation was sensitive to the loading concentration of $\mathrm{TiO}_{2}$ onto 
biochar. The photodegradation efficiency was enhanced owing to the reduced charge recombination. Zhu et al. [91] fabricated biochar-based $\mathrm{g}^{-} \mathrm{C}_{3} \mathrm{~N}_{4}$ for 2-Mercaptobenzothiazole degradation. They proposed that the introduction of biochar can produce more active sites and result in highly efficient of electron-hole pairs separation. Furthermore, BC can significantly inhibit the g- $\mathrm{C}_{3} \mathrm{~N}_{4}$ reunion and stacking.
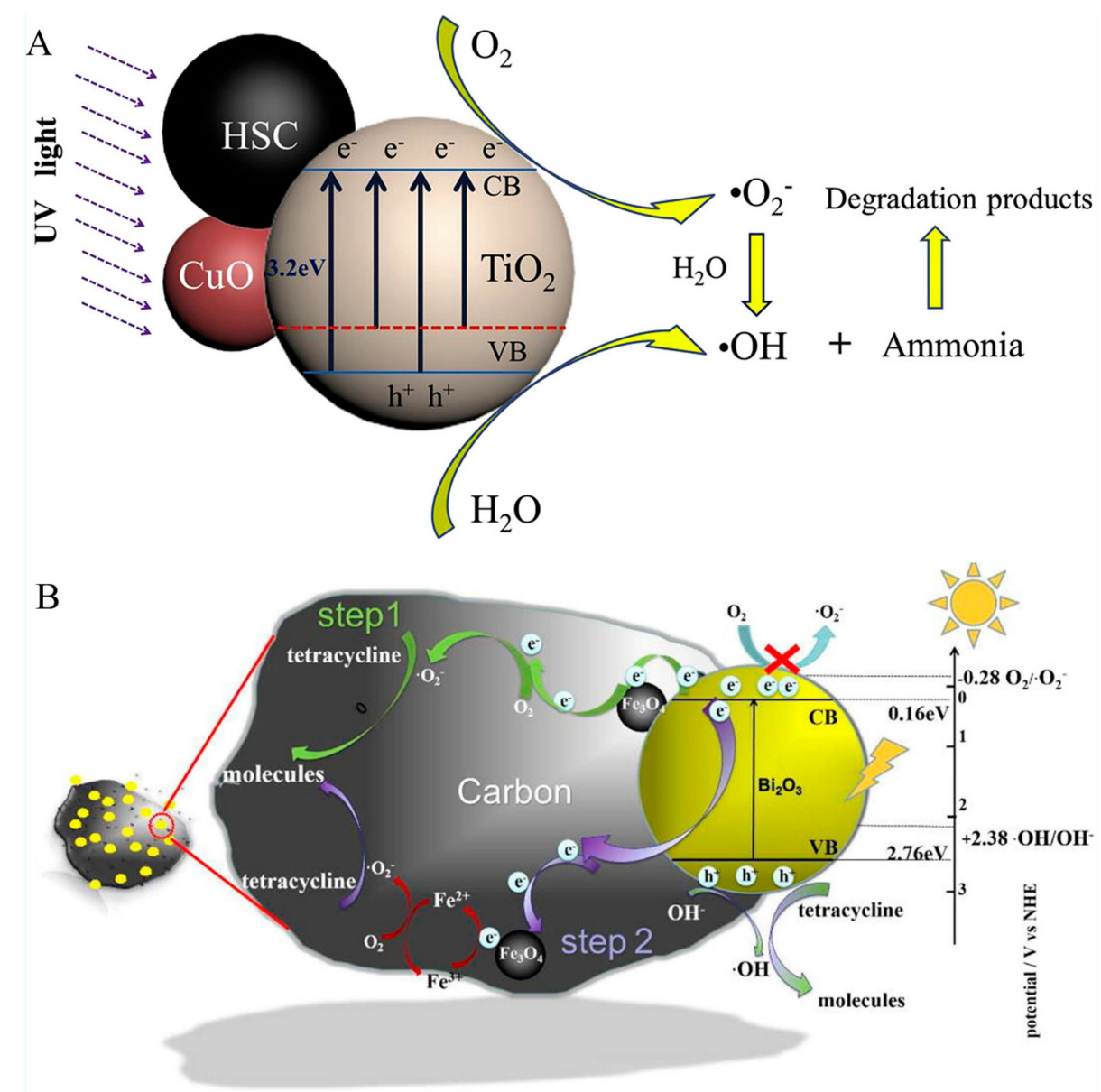

Figure 6. Schematic representation mechanism of suppression of electron-hole recombination. Reproduced with permission from reference [55] (A) and reference [38] (B).

\subsection{Others}

Besides the above-discussed mechanisms, some other effects of biochar were also proposed. Shi et al. [94] prepared $\mathrm{TiO}_{2} / \mathrm{BC}$ (carbonaceous aerogel) composite through a one-pot hydrothermal process. Compared with P25, the composite exhibited excellent photocatalytic activity in MB and CIP degradation under visible-light irradiation. They suggested $B C$ can not only separate the $\mathrm{e}^{-} / \mathrm{H}^{+}$pairs, but also reduce the photocorrosion of $\mathrm{TiO}_{2}$. As the main active species, the $\cdot \mathrm{OH}$ and $\cdot \mathrm{O}_{2}{ }^{-}$radicals promoted the photocatalytic activity. The free radicals present in the matrix could induce $\cdot \mathrm{OH}$ be trapped by oxygen to form superoxide radical anion [95]. Tan et al. [27,96] summarized the interactions between the organic contaminants and BC, including hydrogen bonding, electrostatic attraction, and ion-exchange in the adsorption process. Fang et al. [97] systematically explored the effects of $\mathrm{BC}$ on the transport and transformation of organic contaminants in aquatic systems. It was verified that $B C$ particles could generate ROS, such as $\cdot \mathrm{OH}$ and ${ }^{1} \mathrm{O}_{2}$ through $\mathrm{BC}$ matrix $(\mathrm{BCM})$ and dissolved organic matter (DOM), thus inducing diethyl phthalate degradation under both UV and solar light. 


\section{Applications of BC-based Photocatalysts}

As a kind of sustainable, low-cost, and environment-friendly material, biochar showed a great of advantages when combined with other semiconductors. The microporous structure and large surface area of BCPs was rewarding for efficient diffusion of reactant to the catalytic sites [98]. Moreover, it enhanced the photodegradation ability for various organic substances (phenanthrene [99], phenol [100] and polycyclic aromatic hydrocarbons [101]) and inorganic substances (hexavalent chromium, total chromium [60] and ammonia [55]). As a carbon-rich material, biochar is beneficial for the formation of hierarchical structure carbonaceous nanomaterials, which possesses the advantage of abundant surface functional groups (sulfonyl groups, phenolic groups, acid complexes, etc.). BC serves as alternative carbonaceous nanomaterials, including carbon nanotubes, graphite, $\mathrm{C}_{60}$, carbon fiber, and $\mathrm{g}-\mathrm{C}_{3} \mathrm{~N}_{4}$, etc. [49]. The persistent free radicals contained in biochar can induce the generation of $\cdot \mathrm{O}_{2}$ in the presence of oxygen, which will improve the photocatalytic performance [95]. The applications of various BCPs are summarized in Table 1.

\section{1. $\mathrm{TiO}_{2}-\mathrm{BCPS}$}

During recent decades, $\mathrm{TiO}_{2}$ has been the most used photocatalyst in the field of water purification owing to the advantages of high photo-activity, price moderate, non-toxicity, low cost and good chemical stability [102]. However, pristine $\mathrm{TiO}_{2}$ still suffers from the low response of visible light and high charge recombination. In recent years, biochar modified $\mathrm{TiO}_{2}$ composites $\left(\mathrm{BC}-\mathrm{TiO}_{2}\right)$ have attracted great attention due to the physical adsorption, electrostatic interaction and suppression of electron/hole charges recombination granted by BC.

Zhang et al. [30] synthesized reed straw biochar-based $\mathrm{TiO}_{2}$ by sol-gel method. The coupling of $\mathrm{TiO}_{2}$ and $\mathrm{BC}$ suppressed the recombination of $\mathrm{e}^{-} / \mathrm{h}^{+}$pairs and further promoted photocatalytic degradation efficiency. The sulfamethoxazole removal rate was $91.27 \%$, compared with that of pure $\mathrm{TiO}_{2}(58.47 \%)$. Furthermore, the obtained $\mathrm{BC}-\mathrm{TiO}_{2}$ were successfully applied in real water with a removal rate of $65.70 \%$. Very recently, $\mathrm{Lu}$ et al. [39] fabricated a series of $\mathrm{BC}-\mathrm{TiO}_{2}$ photocatalysts by direct hydrolysis method and pyrolysis of waste walnut shells for the removal of methyl orange. It showed that catalyst with the weight ratio of $0.2 / 1$ (BC/Ti) exhibited the best decolorization efficiency of $92.45 \%$ and mineralization efficiency of $76.56 \%$ after recycling 5 times. Lisowski et al. [41] prepared $\mathrm{TiO}_{2}$-based wood and straw-derived biochar photocatalysts via an ultrasound-assisted route. The prepared composite pyrolyzed at the temperature of $700{ }^{\circ} \mathrm{C}$ had plate-like particles structure, which was beneficial for light use and electron-hole separation. Through Kubelka-Munk function, the band gap energy $\left(\mathrm{E}_{\mathrm{g}}\right)$ of $\mathrm{TiO}_{2}-\mathrm{BC}$ varied from 2.12 to $2.50 \mathrm{eV}$ depending on different biomass feedstocks and temperatures. At the same time, the red-shift in absorption edge of BCPs was observed (Figure 7). They suggested the improved photoabsorption performance and the extended absorption edge was attributed to the introduction of biochar as well as the intimate interfacial contact caused by ultrasound procedure.

\section{2. $g-C_{3} N_{4}-B C P S$}

The graphitic carbon nitride $\left(\mathrm{g}-\mathrm{C}_{3} \mathrm{~N}_{4}\right)$ has elicited ripples in recent years since Wang et al. [103] discovered the hydrogen production from water over $\mathrm{g}-\mathrm{C}_{3} \mathrm{~N}_{4}$ in 2009. $\mathrm{g}-\mathrm{C}_{3} \mathrm{~N}_{4}$ processes high physicochemical stability, non-toxic, and unique graphene-like two-dimensional structure. During recent decades, lots of research on $\mathrm{BC}-\mathrm{g}-\mathrm{C}_{3} \mathrm{~N}_{4}$ conjunctions has been reported. 


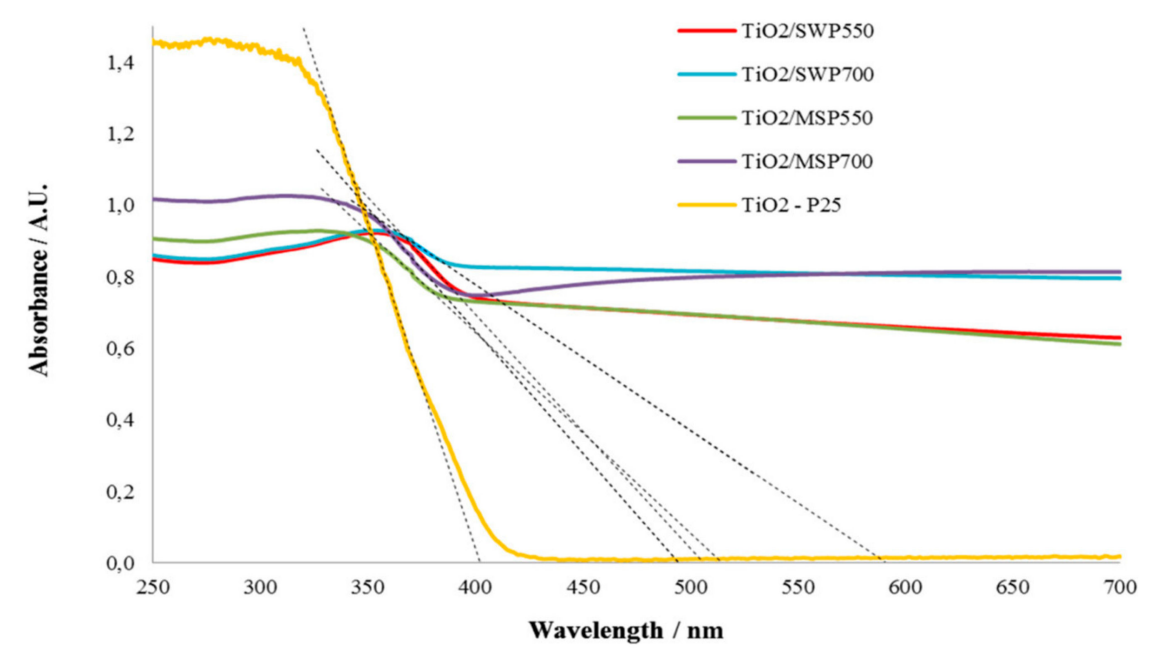

Figure 7. UV-visible diffuse reflectance spectra of $\mathrm{BC}-\mathrm{TiO}_{2}$. Reproduced with permission from reference [41].

Xie et al. [104] summarized the g- $\mathrm{C}_{3} \mathrm{~N}_{4}$-based photocatalysts. The Schottky-junction between g- $\mathrm{C}_{3} \mathrm{~N}_{4}$ and the highly conductive carbon materials enhanced charge separation. Kumar and his co-workers $[37,57,105]$ synthesized a series of BC-based g- $\mathrm{C}_{3} \mathrm{~N}_{4}$ photocatalysts for wastewater treatment. For example, $\mathrm{BC}$ supported g- $\mathrm{C}_{3} \mathrm{~N}_{4} / \mathrm{FeVO}_{4}$ were prepared for methylparaben and 2-chlorophenol photodegradation under solar light [37]. The BCPs exhibited excellent photocatalytic activity with the removal rate of $98.4 \%$ (methylparaben) and $90.7 \%$ (2-chlorophenol), due to the expended solar light response and enhanced charge separation. Recently, Kumar et al. [45] synthesized BC-based g- $\mathrm{C}_{3} \mathrm{~N}_{4} / \mathrm{Bi}_{2} \mathrm{O}_{2} \mathrm{CO}_{3} / \mathrm{CoFe}_{2} \mathrm{O}_{4}$ heterojunction. The high pesticide paraquat removal rate of $99.3 \%$ was reached under visible radiation, compared with that of $92.1 \%$ under solar light. Due to the greater absorption of the visible spectrum, $\mathrm{BC}$ elevated the quantum efficiency, charge separation, and generation of free radicals. Zheng et al. [72] synthesized BC-based g- $\mathrm{C}_{3} \mathrm{~N}_{4}$ via one-pot pyrolysis with different mass ratio. g- $\mathrm{C}_{3} \mathrm{~N}_{4}$ modification can expand biochar's capacity. $\mathrm{BC} 100$ (100 (urea): 1 (biomass)) showed $100 \%$ removal rate of RR120 through both adsorption and photocatalytic degradation under natural conditions. Li et al. [60] fabricated BC coupled g- $\mathrm{C}_{3} \mathrm{~N}_{4}$ nanosheets composites through two-step calcination strategy to remove the $\mathrm{Cr}(\mathrm{VI})$ from wastewater. Graphitized BCPs could completely degrade the $\mathrm{Cr}(\mathrm{VI})$ and total $\mathrm{Cr}$, owing to the photogenerated electrons, high thermal stability, and large specific surface area. Zhang et al. [106] synthesized BC modified graphitic carbon nitride via pyrolysis of kapok fiber. The BCPs presented a narrow band gap and extended light absorption. The $\mathrm{BC}$ facilitated the electron transfer and improved the photocatalytic activity. It played a center role as the carbon source and substrate in the epitaxial growth of graphitic carbon nitride.

\subsection{Bismuth-BCPs}

Bismuth-based photocatalyst has attracted considerable interest in wastewater treatment for its excellent photo-oxidation ability, unique electronic structure and toxic-free properties [107]. Very recently, Zhu et al. [64] prepared bismuth impregnated biochar composites for efficient estrone degradation. They found the $K_{o b s}$ was more than 20 times than that of pristine $\mathrm{Bi} / \mathrm{Bi}_{2} \mathrm{O}_{3}$. The promoted result was owing to the $\cdot \mathrm{OH}$ radicals generated through the synergistic effect between $\mathrm{BC}$ and $\mathrm{Bi} / \mathrm{Bi}_{2} \mathrm{O}_{3}$. $\mathrm{Li}$ et al. [107] synthesized $\mathrm{Bi}_{2} \mathrm{O}_{3} / \mathrm{ZnAl}-\mathrm{LDH}-\mathrm{BC}$ composite, which displayed an excellent performance in photocatalytic degradation of contaminations under visible light. Owing to the synergistic effects between precursors, the $E_{g}$ of the BCPs was lower (2.42), compared with $\mathrm{Bi}_{2} \mathrm{O}_{3}$ and $\mathrm{ZnAl}-\mathrm{LDH}$ (2.75 and 2.9 , respectively). It was found that the light absorption and the separation of $\mathrm{e}^{-} / \mathrm{h}^{+}$pairs was expedited. Moreover, organic contaminants include afranine T, brilliant green, RB and 4-nitrophenol exhibited optimal stability (Figure 8). The BCPs hold great potential in the field of wastewater treatment. 

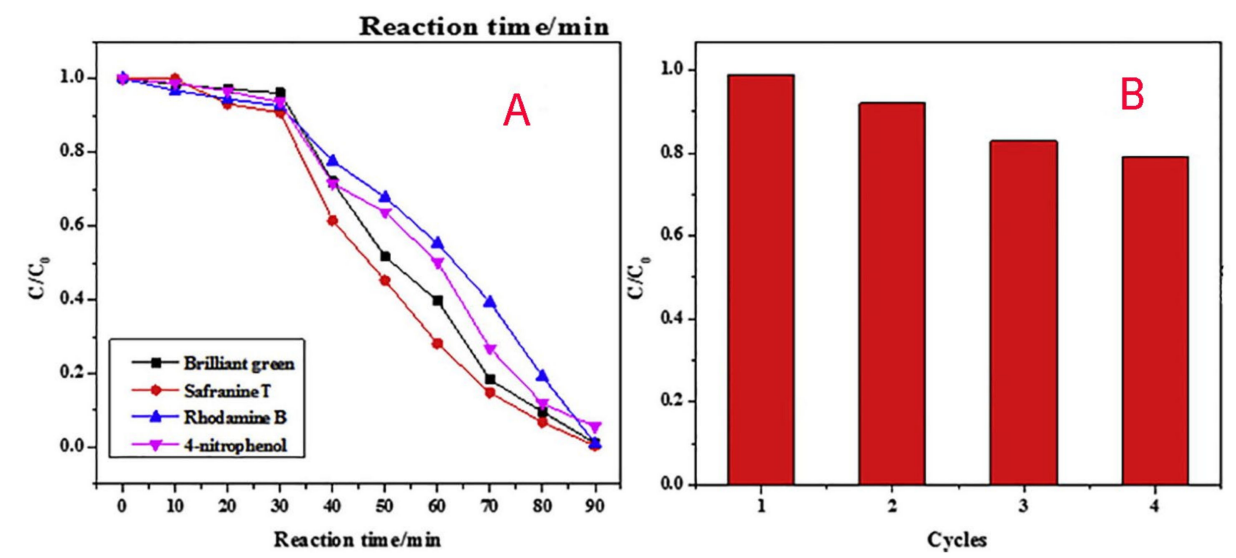

Figure 8. (A) Removal of different organic pollutants over $\mathrm{Bi}_{2} \mathrm{O}_{3} / \mathrm{ZnAl}-\mathrm{LDH}-\mathrm{BC}$, (B) Photocatalysts stability. Reproduced with permission from Ref. [107].

Kumar et al. [60]'s research showed $97.4 \%$ of methylparaben was removed in $2 \mathrm{~h}$ under natural sunlight by $\mathrm{BC}-\mathrm{Fe}_{3} \mathrm{O}_{4}-\mathrm{BiVO}_{4}$ composite. The introduction of $\mathrm{BC}$ brings high surface area, which facilitated the degradation via radical attack and expedited the radical generation. Gao et al. [38] synthesized $\mathrm{BC} / \mathrm{Fe}_{3} \mathrm{O}_{4} / \mathrm{Bi}_{2} \mathrm{O}_{3}$ photocatalyst using corn cobs char. Compared with pure $\mathrm{Bi}_{2} \mathrm{O}_{3}, \mathrm{BC}$ and $\mathrm{BC} / \mathrm{Fe}_{3} \mathrm{O}_{4}$ showed notable red-shift and a broad absorption region. The degradation rate of tetracycline by $\mathrm{BC} / \mathrm{Fe}_{3} \mathrm{O}_{4} / \mathrm{Bi}_{2} \mathrm{O}_{3}-10$ was 2.5 times greater than the bare $\mathrm{Bi}_{2} \mathrm{O}_{3}$. Li et al. [108] found that the increased visible-light absorption was owing to the unique biochar-based heterojunction structure. Bismuth oxyhalides (BiOX) exhibited higher photocatalytic activity than anatase $\mathrm{TiO}_{2}$ due to its unique layered structure interleaved with $\left[\mathrm{Bi}_{2} \mathrm{O}_{2}\right.$ ] slabs and double halogen atoms slabs [51]. Li et al. [109] fabricated a magnetic $\mathrm{Fe}_{3} \mathrm{O}_{4} / \mathrm{BiOBr} / \mathrm{BC}$ (reed straw) composite with the visible-light response via a one-step hydrolysis route. The BCPs exhibited better photocatalytic activity for carbamazepine removal $(95.51 \%)$, owing to the promoted separation of $\mathrm{e}^{-} / \mathrm{h}^{+}$pairs.

\subsection{Carbon Quantum Dots (CQDs)-BCPs}

Carbon quantum dots (CQDs) have emerged as a potential alternative to traditional expensive and unsustainable material [110]. It processes the advantages of high biocompatibility, tunability and stability [111]. The electron transfer, photoluminescence, and electron reservoir properties of the CQDs can enhance the structural stability and photocatalytic activity. Briscoe et al. [110] proposed the preparation method of CQDs mainly includes top-down and bottom-up route. In the top-down way, larger carbon structures are broken into smaller fractions. In contrast, the bottom-up approach involves forming the CQDs from molecular precursors. When biomass precursors are used for the production of CQDs, the latter method exhibited the advantages of sustainability and biocompatibility.

The introduction of biochar-based CQDs (BCQDs) to the semiconductor could lead to the change of band structure and extend the light absorption [112]. Yao et al. [80] prepared BCQDs modified flower-like BiOI composite through the solvothermal method. They found $\mathrm{O}_{2}{ }^{-}$and $\mathrm{h}^{+}$ was the main active species for MB photodegradation. The BCQDs acted as electron acceptors and further facilitated the separation of electron-hole pairs. Recently, Wang et al. [113] prepared BCQDs and $\mathrm{BCQDs} / \mathrm{Ag} / \mathrm{Bi}_{4} \mathrm{Ti}_{3} \mathrm{O}_{12}$ using hydrothermal treatment of bamboo powder. They suggested the introduction of BCQDs facilitated the photoelectron generation and transport. Furthermore, the BCQDs acted as an electron reservoir and boosted the photocatalytic performance.

\section{Summary and Outlook}

This review focus on recent developments related to the treatment of wastewater by BC-based photocatalysts. Various synthesis processes, photocatalytic enhancement mechanisms, and different applications of BCPs were summarized. Semiconductors can be coupled with BC via sol-gel, 
hydrothermal/solvothermal, ultrasound, calcination, and in situ methods. Besides the well-known adsorption effects of $\mathrm{BC}$, it can also narrow the band gap, facilitate the electron transport, suppress the electron-hole charges recombination and reduce the photocorrosion of semiconductor, etc. Moreover, examples for the applications of $\mathrm{BCPs}$ were also summarized, including $\mathrm{TiO}_{2}-\mathrm{BCPs}, \mathrm{g}-\mathrm{C}_{3} \mathrm{~N}_{4}-\mathrm{BCPs}$, Bismuth-BCPs, and CQD-BCPs, etc.

Despite the exciting development of BCPs, some knowledge gaps and issues still exist.

- Most research on the photocatalytic treatment of wastewater through BCPs focused on individual organic or inorganic substance. However, the real wastewater often contains multicomponent of pollutants. There might be competitive adsorption or photocatalysis between different materials during the removal process. Therefore, the performance of $\mathrm{BCPs}$ in treating real wastewater needs to be studied further.

- Recycling significantly reduces the cost of photocatalysis. The reuse of the BCPs from the slurry systems remains a problem, which limits the widespread of their applications. One promising approach to solve this problem is the magnetic separation by applying an external magnetic field in the water treatment process. More research is required to establish the efficient BCPs recovery at large scale.

- Despite its advantages, certain hazardous waste biomass such as sewage sludge and municipal waste could release toxic organic or inorganic substances during the pyrolysis process, thus inducing ecological and health risks. Further research on the assessment of the long-term effects and security of the applications in wastewater treatment needs to be considered.

- By now, most of the research has been carried out in the static system, which is usually applied to test the photocatalytic performance of new catalysts. However, photocatalysis in dynamic conditions may exhibit different abilities. Further investigations are required for the development of BCPs in dynamic photocatalysis system.

Author Contributions: J.C. (Jiali Cui) designed the concept and wrote the first draft of the manuscript. Y.R. and X.Y. contributed with the literature search and illustrations. F.Z., H.L. and J.C. (Jianguo Cui) revised the manuscript. All authors have read and agreed to the published version of the manuscript.

Funding: The authors acknowledge financial support from the Natural Science Foundation of Shanxi (Grant No. 201801D121275), and the Key Research and Development Project of Shanxi (Social Development) (Grant No. 201803D31046).

Conflicts of Interest: The authors declare no conflict of interest.

\section{References}

1. Mian, M.M.; Liu, G. Recent progress in biochar-supported photocatalysts: Synthesis, role of biochar, and applications. RSC Adv. 2018, 8, 14237-14248. [CrossRef]

2. Shaban, Y.A.; El Maradny, A.A.; Al Farawati, R.K. Photocatalytic reduction of nitrate in seawater using $\mathrm{C} / \mathrm{TiO}_{2}$ nanoparticles. J. Photochem. Photobiol. A Chem. 2016, 328, 114-121. [CrossRef]

3. Choi, J.; Park, H.; Hoffmann, M.R. Effects of single metal-ion doping on the visible-light photoreactivity of $\mathrm{TiO}_{2}$. J. Phys. Chem. C 2009, 114, 783-792. [CrossRef]

4. Zhang, Y.; Zhao, Z.; Chen, J.; Cheng, L.; Chang, J.; Sheng, W.; Hu, C.; Cao, S. C-doped hollow $\mathrm{TiO}_{2}$ spheres: In situ synthesis, controlled shell thickness, and superior visible-light photocatalytic activity. Appl. Catal. B Environ. 2015, 165, 715-722. [CrossRef]

5. Asahi, R.; Morikawa, T.; Ohwaki, T.; Aoki, K.; Taga, Y. Visible-light photocatalysis in nitrogen-doped titanium oxides. Science 2001, 293, 269-271. [CrossRef] [PubMed]

6. Devi, L.G.; Kavitha, R. A review on non metal ion doped titania for the photocatalytic degradation of organic pollutants under UV/solar light: Role of photogenerated charge carrier dynamics in enhancing the activity. Appl. Catal. B Environ. 2013, 140, 559-587. [CrossRef]

7. Devi, L.G.; Kavitha, R. Review on modified $\mathrm{N}-\mathrm{TiO}_{2}$ for green energy applications under UV/visible light: Selected results and reaction mechanisms. RSC Adv. 2014, 4, 28265-28299. [CrossRef] 
8. Leary, R.; Westwood, A. Carbonaceous nanomaterials for the enhancement of $\mathrm{TiO}_{2}$ photocatalysis. Carbon 2011, 49, 741-772. [CrossRef]

9. Devi, L.G.; Kavitha, R. Enhanced photocatalytic activity of sulfur doped $\mathrm{TiO}_{2}$ for the decomposition of phenol: A new insight into the bulk and surface modification. Mater. Chem. Phys. 2014, 143, 1300-1308. [CrossRef]

10. Eslami, A.; Amini, M.M.; Yazdanbakhsh, A.R.; Mohseni-Bandpei, A.; Safari, A.A.; Asadi, A. N, S co-doped $\mathrm{TiO}_{2}$ nanoparticles and nanosheets in simulated solar light for photocatalytic degradation of non-steroidal anti-inflammatory drugs in water: A comparative study. J. Chem. Technol. Biotechnol. 2016, 91, $2693-2704$. [CrossRef]

11. Li, H.; Hao, Y.; Lu, H.; Liang, L.; Wang, Y.; Qiu, J.; Shi, X.; Wang, Y.; Yao, J. A systematic study on visible-light $\mathrm{N}$-doped $\mathrm{TiO}_{2}$ photocatalyst obtained from ethylenediamine by sol-gel method. Appl. Surf. Sci. 2015, 344, 112-118. [CrossRef]

12. Giannakas, A.; Antonopoulou, M.; Daikopoulos, C.; Deligiannakis, Y.; Konstantinou, I. Characterization and catalytic performance of B-doped, B-N co-doped and B-N-F tri-doped $\mathrm{TiO}_{2}$ towards simultaneous $\mathrm{Cr}$ (VI) reduction and benzoic acid oxidation. Appl. Catal. B Environ. 2016, 184, 44-54. [CrossRef]

13. Samsudin, E.M.; Hamid, S.B.A.; Juan, J.C.; Basirun, W.J.; Kandjani, A.E.; Bhargava, S.K. Effective role of trifluoroacetic acid (TFA) to enhance the photocatalytic activity of F-doped $\mathrm{TiO}_{2}$ prepared by modified sol-gel method. Appl. Surf. Sci. 2016, 365, 57-68. [CrossRef]

14. Samsudin, E.M.; Hamid, S.B.A.; Juan, J.C.; Basirun, W.J.; Centi, G. Synergetic effects in novel hydrogenated F-doped $\mathrm{TiO}_{2}$ photocatalysts. Appl. Surf. Sci. 2016, 370, 380-393. [CrossRef]

15. Mendiola-Alvarez, S.; Hernández-Ramírez, A.; Guzmán-Mar, J.; Maya-Treviño, M.; Caballero-Quintero, A.; Hinojosa-Reyes, L. A novel P-doped $\mathrm{Fe}_{2} \mathrm{O}_{3}-\mathrm{TiO}_{2}$ mixed oxide: Synthesis, characterization and photocatalytic activity under visible radiation. Catal. Today 2019, 328, 91-98. [CrossRef]

16. Lai, Y.-K.; Huang, J.-Y.; Zhang, H.-F.; Subramaniam, V.-P.; Tang, Y.-X.; Gong, D.-G.; Sundar, L.; Sun, L.; Chen, Z.; Lin, C.-J. Nitrogen-doped TiO2 nanotube array films with enhanced photocatalytic activity under various light sources. J. Hazard. Mater. 2010, 184, 855-863. [CrossRef]

17. Jyothi, M.; Nayak, V.; Reddy, K.R.; Naveen, S.; Raghu, A. Non-metal (Oxygen, Sulphur, Nitrogen, Boron and Phosphorus)-Doped Metal Oxide Hybrid Nanostructures as Highly Efficient Photocatalysts for Water Treatment and Hydrogen Generation. In Nanophotocatalysis and Environmental Applications; Springer: Berlin/Heidelberg, Germany, 2019; pp. 83-105.

18. Khan, S.U.M.; Al-Shahry, M.; Ingler, W.B. Efficient Photochemical Water Splitting by a Chemically Modified $\mathrm{n}-\mathrm{TiO}_{2}$. Science 2002, 297, 2243-2245. [CrossRef]

19. Sakthivel, S.; Kisch, H. Daylight Photocatalysis by Carbon-Modified Titanium Dioxide. Angew. Chem. Int. Ed. 2003, 42, 4908-4911. [CrossRef]

20. Chen, D.; Jiang, Z.; Geng, J.; Wang, Q.; Yang, D. Carbon and Nitrogen Co-doped $\mathrm{TiO}_{2}$ with Enhanced Visible-Light Photocatalytic Activity. Ind. Eng. Chem. Res. 2007, 46, 2741-2746. [CrossRef]

21. Wang, H.; Lewis, J.P. Effects of dopant states on photoactivity in carbon-doped $\mathrm{TiO}_{2}$. J. Phys. Condens. Matter 2005, 17, L209. [CrossRef]

22. Colmenares, J.C.; Varma, R.S.; Lisowski, P. Sustainable hybrid photocatalysts: titania immobilized on carbon materials derived from renewable and biodegradable resources. Green Chem. 2016, 18, 5736-5750. [CrossRef]

23. Luo, M.; Lin, H.; Li, B.; Dong, Y.; He, Y.; Wang, L. A novel modification of lignin on corncob-based biochar to enhance removal of cadmium from water. Bioresour. Technol. 2018, 259, 312-318. [CrossRef] [PubMed]

24. Li, H.; Dong, X.; Da Silva, E.B.; De Oliveira, L.M.; Chen, Y.; Ma, L.Q. Mechanisms of metal sorption by biochars: biochar characteristics and modifications. Chemosphere 2017, 178, 466-478. [CrossRef] [PubMed]

25. Lee, D.-J.; Cheng, Y.-L.; Wong, R.-J.; Wang, X.-D. Adsorption removal of natural organic matters in waters using biochar. Bioresour. Technol. 2018, 260, 413-416. [CrossRef]

26. Fang, G.; Liu, C.; Gao, J.; Dionysiou, D.D.; Zhou, D. Manipulation of persistent free radicals in biochar to activate persulfate for contaminant degradation. Environ. Sci. Technol. 2015, 49, 5645-5653. [CrossRef]

27. Tan, X.; Liu, Y.; Zeng, G.; Wang, X.; Hu, X.; Gu, Y.; Yang, Z. Application of biochar for the removal of pollutants from aqueous solutions. Chemosphere 2015, 125, 70-85. [CrossRef]

28. Zhang, S.; Lu, X. Treatment of wastewater containing Reactive Brilliant Blue $\mathrm{KN}-\mathrm{R}$ using $\mathrm{TiO}_{2} / \mathrm{BC}$ composite as heterogeneous photocatalyst and adsorbent. Chemosphere 2018, 206, 777-783. [CrossRef] 
29. Silvestri, S.; Gonçalves, M.G.; Da Silva Veiga, P.A.; Matos, T.T.D.S.; Peralta-Zamora, P.; Mangrich, A.S. TiO 2 supported on Salvinia molesta biochar for heterogeneous photocatalytic degradation of Acid Orange 7 dye. J. Environ. Chem. Eng. 2019, 7, 102879. [CrossRef]

30. Zhang, H.; Wang, Z.; Li, R.; Guo, J.; Li, Y.; Zhu, J.; Xie, X. TiO 2 supported on reed straw biochar as an adsorptive and photocatalytic composite for the efficient degradation of sulfamethoxazole in aqueous matrices. Chemosphere 2017, 185, 351-360. [CrossRef]

31. Cai, X.; Li, J.; Liu, Y.; Yan, Z.; Tan, X.; Liu, S.; Zeng, G.; Gu, Y.; Hu, X.; Jiang, L. Titanium dioxide-coated biochar composites as adsorptive and photocatalytic degradation materials for the removal of aqueous organic pollutants. J. Chem. Technol. Biotechnol. 2018, 93, 783-791. [CrossRef]

32. Kim, J.R.; Kan, E. Heterogeneous photocatalytic degradation of sulfamethoxazole in water using a biochar-supported $\mathrm{TiO}_{2}$ photocatalyst. J. Environ. Manag. 2016, 180, 94-101. [CrossRef]

33. Khataee, A.; Kayan, B.; Gholami, P.; Kalderis, D.; Akay, S. Sonocatalytic degradation of an anthraquinone dye using TiO2-biochar nanocomposite. Ultrason. Sonochem. 2017, 39, 120-128. [CrossRef] [PubMed]

34. Wang, B.; Liu, B.; Ji, X.-X.; Ma, M.-G. Synthesis, characterization, and photocatalytic properties of bamboo charcoal/ $/ \mathrm{TiO}_{2}$ composites using four sizes powder. Materials 2018, 11, 670. [CrossRef] [PubMed]

35. Men, Q.; Wang, T.; Ma, C.; Yang, L.; Liu, Y.; Huo, P.; Yan, Y. In-suit preparation of CdSe quantum dots/porous channel biochar for improving photocatalytic activity for degradation of tetracycline. J. Taiwan Inst. Chem. Eng. 2019, 99, 180-192. [CrossRef]

36. Vinayagam, M.; Ramachandran, S.; Ramya, V.; Sivasamy, A. Photocatalytic degradation of orange G dye using $\mathrm{ZnO}$ /biomass activated carbon nanocomposite. J. Environ. Chem. Eng. 2018, 6, 3726-3734. [CrossRef]

37. Kumar, A.; Kumar, A.; Sharma, G.; Naushad, M.; Stadler, F.J.; Ghfar, A.A.; Dhiman, P.; Saini, R.V. Sustainable nano-hybrids of magnetic biochar supported $\mathrm{g}-\mathrm{C}_{3} \mathrm{~N}_{4} / \mathrm{FeVO}_{4}$ for solar powered degradation of noxious pollutants- Synergism of adsorption, photocatalysis \& photo-ozonation. J. Clean. Prod. 2017, 165, 431-451.

38. Gao, N.; Lu, Z.; Zhao, X.; Zhu, Z.; Wang, Y.; Wang, D.; Hua, Z.; Li, C.; Huo, P.; Song, M. Enhanced photocatalytic activity of a double conductive $\mathrm{C} / \mathrm{Fe}_{3} \mathrm{O}_{4} / \mathrm{Bi}_{2} \mathrm{O}_{3}$ composite photocatalyst based on biomass. Chem. Eng. J. 2016, 304, 351-361. [CrossRef]

39. Lu, L.; Shan, R.; Shi, Y.; Wang, S.; Yuan, H. A novel $\mathrm{TiO}_{2} /$ biochar composite catalysts for photocatalytic degradation of methyl orange. Chemosphere 2019, 222, 391-398. [CrossRef]

40. Djellabi, R.; Yang, B.; Wang, Y.; Cui, X.; Zhao, X. Carbonaceous biomass-titania composites with TiOC bonding bridge for efficient photocatalytic reduction of $\mathrm{Cr}(\mathrm{VI})$ under narrow visible light. Chem. Eng. J. 2019, 366, 172-180. [CrossRef]

41. Lisowski, P.; Colmenares, J.C.; Mašek, O.; Lisowski, W.; Lisovytskiy, D.; Kamińska, A.; Łomot, D. Dual Functionality of $\mathrm{TiO}_{2} /$ Biochar Hybrid Materials: Photocatalytic Phenol Degradation in the Liquid Phase and Selective Oxidation of Methanol in the Gas Phase. ACS Sustain. Chem. Eng. 2017, 5, 6274-6287. [CrossRef]

42. Matos, J. Eco-friendly heterogeneous photocatalysis on biochar-based materials under solar irradiation. Top. Catal. 2016, 59, 394-402. [CrossRef]

43. Xue, H.; Chen, Y.; Liu, X.; Qian, Q.; Luo, Y.; Cui, M.; Chen, Y.; Yang, D.-P.; Chen, Q. Visible light-assisted efficient degradation of dye pollutants with biomass-supported $\mathrm{TiO}_{2}$ hybrids. Mater. Sci. Eng. C 2018, 82, 197-203. [CrossRef]

44. Xie, X.; Li, S.; Zhang, H.; Wang, Z.; Huang, H. Promoting charge separation of biochar-based Zn-TiO $2 / \mathrm{pBC}$ in the presence of $\mathrm{ZnO}$ for efficient sulfamethoxazole photodegradation under visible light irradiation. Sci. Total Environ. 2019, 659, 529-539. [CrossRef]

45. Kumar, A.; Kumar, A.; Sharma, G.; Al-Muhtaseb, A.A.H.; Naushad, M.; Ghfar, A.A.; Guo, C.; Stadler, F.J. Biochar-templated g- $\mathrm{C}_{3} \mathrm{~N}_{4} / \mathrm{Bi}_{2} \mathrm{O}_{2} \mathrm{CO}_{3} / \mathrm{CoFe}_{2} \mathrm{O}_{4}$ nano-assembly for visible and solar assisted photo-degradation of paraquat, nitrophenol reduction and $\mathrm{CO}_{2}$ conversion. Chem. Eng. J. 2018, 339, 393-410. [CrossRef]

46. Donar, Y.O.; Bilge, S.; Sinağ, A.; Pliekhov, O. $\mathrm{TiO}_{2} /$ Carbon Materials Derived from Hydrothermal Carbonization of Waste Biomass: A Highly Efficient, Low-Cost Visible-Light-Driven Photocatalyst. ChemCatChem 2018, 10, 1134-1139. [CrossRef]

47. Peñas-Garzón, M.; Gómez-Avilés, A.; Bedia, J.; Rodriguez, J.J.; Belver, C. Effect of Activating Agent on the Properties of $\mathrm{TiO}_{2} /$ Activated Carbon Heterostructures for Solar Photocatalytic Degradation of Acetaminophen. Materials 2019, 12, 378. [CrossRef] 
48. Wang, T.; Liu, S.; Mao, W.; Bai, Y.; Chiang, K.; Shah, K.; Paz-Ferreiro, J. Novel Bi $2 \mathrm{WO}_{6}$ loaded N-biochar composites with enhanced photocatalytic degradation of rhodamine B and Cr (VI). J. Hazard. Mater. 2019. [CrossRef]

49. Gholami, P.; Khataee, A.; Soltani, R.D.C.; Dinpazhoh, L.; Bhatnagar, A. Photocatalytic degradation of gemifloxacin antibiotic using Zn-Co-LDH@biochar nanocomposite. J. Hazard. Mater. 2020, 382, 121070. [CrossRef]

50. Ye, S.; Yan, M.; Tan, X.; Liang, J.; Zeng, G.; Wu, H.; Song, B.; Zhou, C.; Yang, Y.; Wang, H. Facile assembled biochar-based nanocomposite with improved graphitization for efficient photocatalytic activity driven by visible light. Appl. Catal. B Environ. 2019, 250, 78-88. [CrossRef]

51. Li, M.; Huang, H.; Yu, S.; Tian, N.; Dong, F.; Du, X.; Zhang, Y. Simultaneously promoting charge separation and photoabsorption of $\mathrm{BiOX}(\mathrm{X}=\mathrm{Cl}, \mathrm{Br})$ for efficient visible-light photocatalysis and photosensitization by compositing low-cost biochar. Appl. Surf. Sci. 2016, 386, 285-295. [CrossRef]

52. Liu, M.Y.; Zheng, Y.F.; Song, X.C. Biomass Assisted Synthesis of 3D Hierarchical Structure BiOX (X Cl, Br)-(CMC) with Enhanced Photocatalytic Activity. J. Nanosci. Nanotechnol. 2019, 19, 5287-5294. [CrossRef] [PubMed]

53. Cai, F.-Y.; Zhang, Y.-Q.; Wang, J.-T.; Zhou, J.-R.; Cao, H.-L.; Lü, J. Mixed phase nano-CdS supported on activated biomass carbon as efficient visible light-driven photocatalysts. Environ. Sci. Pollut. Res. 2019, 26, 31055-31061. [CrossRef] [PubMed]

54. Lisowski, P.; Colmenares, J.C.; Mašek, O.; Lisowski, W.; Lisovytskiy, D.; Grzonka, J.; Kurzydłowski, K. Design and Fabrication of $\mathrm{TiO}_{2}$ /Lignocellulosic Carbon Materials: Relevance of Low-temperature Sonocrystallization to Photocatalysts Performance. ChemCatChem 2018, 10, 3469-3480. [CrossRef]

55. Peng, X.; Wang, M.; Hu, F.; Qiu, F.; Dai, H.; Cao, Z. Facile fabrication of hollow biochar carbon-doped $\mathrm{TiO}_{2} / \mathrm{CuO}$ composites for the photocatalytic degradation of ammonia nitrogen from aqueous solution. J. Alloys Compd. 2019, 770, 1055-1063. [CrossRef]

56. Huang, H.-B.; Wang, Y.; Jiao, W.-B.; Cai, F.-Y.; Shen, M.; Zhou, S.-G.; Cao, H.-L.; Lü, J.; Cao, R. Lotus-Leaf-Derived Activated-Carbon-Supported Nano-CdS as Energy-Efficient Photocatalysts under Visible Irradiation. ACS Sustain. Chem. Eng. 2018, 6, 7871-7879. [CrossRef]

57. Li, K.; Huang, Z.; Zhu, S.; Luo, S.; Yan, L.; Dai, Y.; Guo, Y.; Yang, Y. Removal of Cr(VI) from water by a biochar-coupled $\mathrm{g}-\mathrm{C}_{3} \mathrm{~N}_{4}$ nanosheets composite and performance of a recycled photocatalyst in single and combined pollution systems. Appl. Catal. B Environ. 2019, 243, 386-396. [CrossRef]

58. Cruz, G.J.F.; Gómez, M.M.; Solis, J.L.; Rimaycuna, J.; Solis, R.L.; Cruz, J.F.; Rathnayake, B.; Keiski, R.L. Composites of $\mathrm{ZnO}$ nanoparticles and biomass based activated carbon: adsorption, photocatalytic and antibacterial capacities. Water Sci. Technol. 2018, 2017, 492-508. [CrossRef]

59. Zhai, Y.; Dai, Y.; Guo, J.; Zhou, L.; Chen, M.; Yang,H.; Peng, L. Novel biochar@CoFe $\mathrm{O}_{4} / \mathrm{Ag}_{3} \mathrm{PO}_{4}$ photocatalysts for highly efficient degradation of bisphenol a under visible-light irradiation. J. Colloid Interface Sci. 2020, 560, 111-121. [CrossRef]

60. Kumar, A.; Sharma, G.; Naushad, M.; Kumar, A.; Kalia, S.; Guo, C.; Mola, G.T. Facile hetero-assembly of superparamagnetic $\mathrm{Fe}_{3} \mathrm{O}_{4} / \mathrm{BiVO}_{4}$ stacked on biochar for solar photo-degradation of methyl paraben and pesticide removal from soil. J. Photochem. Photobiol. A Chem. 2017, 337, 118-131. [CrossRef]

61. Kumar, A.; Sharma, G.; Naushad, M.; Al-Muhtaseb, A.A.H.; Kumar, A.; Hira, I.; Ahamad, T.; Ghfar, A.A.; Stadler, F.J. Visible photodegradation of ibuprofen and 2,4-D in simulated waste water using sustainable metal free-hybrids based on carbon nitride and biochar. J. Environ. Manag. 2019, 231, 1164-1175. [CrossRef]

62. Lisowski, P.; Colmenares, J.C.; Mašek, O.; Łomot, D.; Chernyayeva, O.; Lisovytskiy, D. Novel biomass-derived hybrid $\mathrm{TiO}_{2}$ /carbon material using tar-derived secondary char to improve $\mathrm{TiO}_{2}$ bonding to carbon matrix. J. Anal. Appl. Pyrolysis 2018, 131, 35-41. [CrossRef]

63. Fazal, T.; Razzaq, A.; Javed, F.; Hafeez, A.; Rashid, N.; Amjad, U.S.; Rehman, M.S.U.; Faisal, A.; Rehman, F. Integrating adsorption and photocatalysis: A cost effective strategy for textile wastewater treatment using hybrid biochar- $\mathrm{TiO}_{2}$ composite. J. Hazard. Mater. 2019. [CrossRef]

64. Zhu, N.; Li, C.; Bu, L.; Tang, C.; Wang, S.; Duan, P.; Yao, L.; Tang, J.; Dionysiou, D.D.; Wu, Y. Bismuth impregnated biochar for efficient estrone degradation: The synergistic effect between biochar and $\mathrm{Bi} / \mathrm{Bi}_{2} \mathrm{O}_{3}$ for a high photocatalytic performance. J. Hazard. Mater. 2020, 384, 121258. [CrossRef] 
65. Mamaghani, A.H.; Haghighat, F.; Lee, C.-S. Hydrothermal/solvothermal synthesis and treatment of $\mathrm{TiO}_{2}$ for photocatalytic degradation of air pollutants: Preparation, characterization, properties, and performance. Chemosphere 2019, 219, 804-825. [CrossRef]

66. Lisowski, P.; Colmenares, J.C.; Łomot, D.; Chernyayeva, O.; Lisovytskiy, D. Preparation by sonophotodeposition method of bimetallic photocatalysts $\mathrm{Pd}-\mathrm{Cu} / \mathrm{TiO}_{2}$ for sustainable gaseous selective oxidation of methanol to methyl formate. J. Mol. Catal. A Chem. 2016, 411, 247-256. [CrossRef]

67. Brandes, R.; Trindade, E.C.A.; Vanin, D.F.; Vargas, V.M.M.; Carminatti, C.A.; Al-Qureshi, H.A.; Recouvreux, D.O.S. Spherical Bacterial Cellulose/ $\mathrm{TiO}_{2}$ Nanocomposite with Potential Application in Contaminants Removal from Wastewater by Photocatalysis. Fibers Polym. 2018, 19, 1861-1868. [CrossRef]

68. Zhao, B.; O'connor, D.; Zhang, J.; Peng, T.; Shen, Z.; Tsang, D.C.W.; Hou, D. Effect of pyrolysis temperature, heating rate, and residence time on rapeseed stem derived biochar. J. Clean. Prod. 2018, 174, 977-987. [CrossRef]

69. Abdul, G.; Zhu, X.; Chen, B. Structural characteristics of biochar-graphene nanosheet composites and their adsorption performance for phthalic acid esters. Chem. Eng. J. 2017, 319, 9-20. [CrossRef]

70. Xiao, X.; Chen, B. A direct observation of the fine aromatic clusters and molecular structures of biochars. Environ. Sci. Technol. 2017, 51, 5473-5482. [CrossRef]

71. Fan, S.; Wang, Y.; Wang, Z.; Tang, J.; Tang, J.; Li, X. Removal of methylene blue from aqueous solution by sewage sludge-derived biochar: Adsorption kinetics, equilibrium, thermodynamics and mechanism. J. Environ. Chem. Eng. 2017, 5, 601-611. [CrossRef]

72. Zheng, Y.; Yang, Y.; Zhang, Y.; Zou, W.; Luo, Y.; Dong, L.; Gao, B. Facile one-step synthesis of graphitic carbon nitride-modified biochar for the removal of reactive red 120 through adsorption and photocatalytic degradation. Biochar 2019, 1, 89-96. [CrossRef]

73. Geng, A.; Meng, L.; Han, J.; Zhong, Q.; Li, M.; Han, S.; Mei, C.; Xu, L.; Tan, L.; Gan, L. Highly efficient visible-light photocatalyst based on cellulose derived carbon nanofiber/BiOBr composites. Cellulose 2018, 25, 4133-4144. [CrossRef]

74. Ren, W.; Ai, Z.; Jia, F.; Zhang, L.; Fan, X.; Zou, Z. Low temperature preparation and visible light photocatalytic activity of mesoporous carbon-doped crystalline $\mathrm{TiO}_{2}$. Appl. Catal. B Environ. 2007, 69, 138-144. [CrossRef]

75. Al-Kahtani, A.A.; Alshehri, S.M.; Naushad, M.; Ruksana; Ahamad, T. Fabrication of highly porous N/S doped carbon embedded with ZnS as highly efficient photocatalyst for degradation of bisphenol. Int. J. Biol. Macromol. 2019, 121, 415-423. [CrossRef] [PubMed]

76. Wong, J.W.C.; Webber, J.B.W.; Ogbonnaya, U.O. Characteristics of biochar porosity by NMR and study of ammonium ion adsorption. J. Anal. Appl. Pyrolysis 2019, 143, 104687. [CrossRef]

77. Zhong, Y.; Deng, Q.; Zhang, P.; Wang, J.; Wang, R.; Zeng, Z.; Deng, S. Sulfonic acid functionalized hydrophobic mesoporous biochar: Design, preparation and acid-catalytic properties. Fuel 2019, 240, 270-277. [CrossRef]

78. Jiang, Y.; Ren, C.; Guo, H.; Guo, M.; Li, W. Speciation Transformation of Phosphorus in Poultry Litter during Pyrolysis: Insights from XRD, FTIR, and Solid-state NMR Spectroscopy. Environ. Sci. Technol. 2019, 53, 13841-13849. [CrossRef]

79. Igalavithana, A.D.; Mandal, S.; Niazi, N.K.; Vithanage, M.; Parikh, S.J.; Mukome, F.N.; Rizwan, M.; Oleszczuk, P.; Al-Wabel, M.; Bolan, N. Advances and future directions of biochar characterization methods and applications. Crit. Rev. Environ. Sci. Technol. 2017, 47, 2275-2330. [CrossRef]

80. Yao, X.; Ma, C.; Huang, H.; Zhu, Z.; Dong, H.; Li, C.; Zhang, W.; Yan, Y.; Liu, Y. Solvothermal-Assisted Synthesis of Biomass Carbon Quantum Dots/Bismuth Oxyiodide Microflower for Enhanced Photocatalytic Activity. Nano 2018, 13, 1850031. [CrossRef]

81. Xiong, X.; Yu, I.K.M.; Chen, S.S.; Tsang, D.C.W.; Cao, L.; Song, H.; Kwon, E.E.; Ok, Y.S.; Zhang, S.; Poon, C.S. Sulfonated biochar as acid catalyst for sugar hydrolysis and dehydration. Catal. Today 2018, 314, 52-61. [CrossRef]

82. Zou, W.; Gao, B.; Ok, Y.S.; Dong, L. Integrated adsorption and photocatalytic degradation of volatile organic compounds (VOCs) using carbon-based nanocomposites: A critical review. Chemosphere 2019, 218, 845-859. [CrossRef] [PubMed]

83. Di Valentin, C.; Pacchioni, G.; Selloni, A. Theory of carbon doping of titanium dioxide. Chem. Mater. 2005, 17, 6656-6665. [CrossRef]

84. Yin, G.; Wang, Y.; Yuan, Q. $\mathrm{Ti}^{3+}$-doped $\mathrm{TiO}_{2}$ hollow sphere with mixed phases of anatase and rutile prepared by dual-frequency atmospheric pressure plasma jet. J. Nanopart. Res. 2018, 20, 208. [CrossRef] 
85. Low, F.W.; Lai, C.W.; Hamid, S.B.A. Surface modification of reduced graphene oxide film by Ti ion implantation technique for high dye-sensitized solar cells performance. Ceram. Int. 2017, 43, 625-633. [CrossRef]

86. Lu, Z.; Zeng, L.; Song, W.; Qin, Z.; Zeng, D.; Xie, C. In situ synthesis of C- $\mathrm{TiO}_{2} / g-\mathrm{C}_{3} \mathrm{~N}_{4}$ heterojunction nanocomposite as highly visible light active photocatalyst originated from effective interfacial charge transfer. Appl. Catal. B Environ. 2017, 202, 489-499. [CrossRef]

87. Khalid, N.; Majid, A.; Tahir, M.B.; Niaz, N.; Khalid, S. Carbonaceous-TiO 2 nanomaterials for photocatalytic degradation of pollutants: A review. Ceram. Int. 2017, 43, 14552-14571. [CrossRef]

88. Hideyuki, K.; Takahisa, A.; Koichi, Y. Theoretical study of the structure and optical properties of carbon-doped rutile and anatase titanium oxides. J. Chem. Phys. 2005, 123, 37.

89. Djellabi, R.; Yang, B.; Xiao, K.; Gong, Y.; Cao, D.; Sharif, H.M.A.; Zhao, X.; Zhu, C.; Zhang, J. Unravelling the mechanistic role of TiOC bonding bridge at titania/lignocellulosic biomass interface for $\mathrm{Cr}$ (VI) photoreduction under visible light. J. Colloid Interface Sci. 2019, 553, 409-417. [CrossRef] [PubMed]

90. Bao, N.; Li, Y.; Wei, Z.; Yin, G.; Niu, J. Adsorption of dyes on hierarchical mesoporous $\mathrm{Tio}_{2}$ fibers and its enhanced photocatalytic properties. J. Phys. Chem. C 2011, 115, 5708-5719. [CrossRef]

91. Zhu, Z.; Fan, W.; Liu, Z.; Yu, Y.; Dong, H.; Huo, P.; Yan, Y. Fabrication of the metal-free biochar-based graphitic carbon nitride for improved 2-Mercaptobenzothiazole degradation activity. J. Photochem. Photobiol. A Chem. 2018, 358, 284-293. [CrossRef]

92. Meng, L.; Yin, W.; Wang, S.; Wu, X.; Hou, J.; Yin, W.; Feng, K.; Ok, Y.S.; Wang, X. Photocatalytic behavior of biochar-modified carbon nitride with enriched visible-light reactivity. Chemosphere 2020, 239, 124713. [CrossRef] [PubMed]

93. Zhao, X.; Lu, Z.; Ji, R.; Zhang, M.; Yi, C.; Yan, Y. Biomass carbon modified Z-scheme g- $\mathrm{C}_{3} \mathrm{~N}_{4} / \mathrm{Co}_{3} \mathrm{O}_{4}$ heterojunction with enhanced visible-light photocatalytic activity. Catal. Commun. 2018, 112, 49-52. [CrossRef]

94. Shi, M.; Wei, W.; Jiang, Z.; Han, H.; Gao, J.; Xie, J. Biomass-derived multifunctional $\mathrm{TiO}_{2} /$ carbonaceous aerogel composite as a highly efficient photocatalyst. RSC Adv. 2016, 6, 25255-25266. [CrossRef]

95. Fang, G.; Zhu, C.; Dionysiou, D.D.; Gao, J.; Zhou, D. Mechanism of hydroxyl radical generation from biochar suspensions: Implications to diethyl phthalate degradation. Bioresour. Technol. 2015, 176, 210-217. [CrossRef]

96. Tan, X.-F.; Liu, Y.-G.; Gu, Y.-L.; Xu, Y.; Zeng, G.-M.; Hu, X.-J.; Liu, S.-B.; Wang, X.; Liu, S.-M.; Li, J. Biochar-based nano-composites for the decontamination of wastewater: A review. Bioresour. Technol. 2016, 212, 318-333. [CrossRef]

97. Fang, G.; Liu, C.; Wang, Y.; Dionysiou, D.D.; Zhou, D. Photogeneration of reactive oxygen species from biochar suspension for diethyl phthalate degradation. Appl. Catal. B Environ. 2017, 214, 34-45. [CrossRef]

98. Wan, J.; Sun, L.; Fan, J.; Liu, E.; Hu, X.; Tang, C.; Yin, Y. Facile synthesis of porous $\mathrm{Ag}_{3} \mathrm{PO}_{4}$ nanotubes for enhanced photocatalytic activity under visible light. Appl. Surf. Sci. 2015, 355, 615-622. [CrossRef]

99. Jin, J.; Sun, K.; Wang, Z.; Yang, Y.; Han, L.; Xing, B. Characterization and phenanthrene sorption of natural and pyrogenic organic matter fractions. Environ. Sci. Technol. 2017, 51, 2635-2642. [CrossRef]

100. Shi, S.; Liu, J.; Xu, J.; Zeng, Q.; Hou, Y.; Jiang, B. Effects of biochar on the phenol treatment performance and microbial communities shift in sequencing batch reactors. Water Res. 2019, 161, 1-10. [CrossRef]

101. Dutta, T.; Kwon, E.; Bhattacharya, S.S.; Jeon, B.H.; Deep, A.; Uchimiya, M.; Kim, K.-H. Polycyclic aromatic hydrocarbons and volatile organic compounds in biochar and biochar-amended soil: A review. Gcb Bioenergy 2017, 9, 990-1004. [CrossRef]

102. Meng, A.; Zhang, L.; Cheng, B.; Yu, J. Dual Cocatalysts in $\mathrm{TiO}_{2}$ Photocatalysis. Adv. Mater. 2019, 31, 1807660. [CrossRef]

103. Wang, X.; Maeda, K.; Thomas, A.; Takanabe, K.; Xin, G.; Carlsson, J.M.; Domen, K.; Antonietti, M. A metal-free polymeric photocatalyst for hydrogen production from water under visible light. Nat. Mater. 2009, 8, 76. [CrossRef]

104. Wen, J.; Xie, J.; Chen, X.; Li, X. A review on g- $\mathrm{C}_{3} \mathrm{~N}_{4}$-based photocatalysts. Appl. Surf. Sci. 2017, 391, 72-123. [CrossRef]

105. Kumar, A.; Kumar, A.; Sharma, G.; Ala'a, H.; Naushad, M.; Ghfar, A.A.; Stadler, F.J. Quaternary magnetic $\mathrm{BiOCl} / \mathrm{g}-\mathrm{C}_{3} \mathrm{~N}_{4} / \mathrm{Cu}_{2} \mathrm{O} / \mathrm{Fe}_{3} \mathrm{O}_{4}$ nano-junction for visible light and solar powered degradation of sulfamethoxazole from aqueous environment. Chem. Eng. J. 2018, 334, 462-478. [CrossRef] 
106. Zhang, L.; Jin, Z.; Huang, S.; Huang, X.; Xu, B.; Hu, L.; Cui, H.; Ruan, S.; Zeng, Y.-J. Bio-inspired carbon doped graphitic carbon nitride with booming photocatalytic hydrogen evolution. Appl. Catal. B Environ. 2019, 246, 61-71. [CrossRef]

107. Li, C.; Zhao, G.; Yan, T.; Zhang, T.; Liu, X.; Long, X.; Duan, H.; Jiao, F. Enhanced visible-light-induced photocatalytic performance of $\mathrm{Bi}_{2} \mathrm{O}_{3} / \mathrm{ZnAl}-\mathrm{LDH}-\mathrm{C}$ for dyes removal in water. Mater. Lett. 2019, 244, $215-218$. [CrossRef]

108. Li, S.; Wang, Z.; Xie, X.; Liang, G.; Cai, X.; Zhang, X.; Wang, Z. Fabrication of vessel-like biochar-based heterojunction photocatalyst $\mathrm{Bi}_{2} \mathrm{~S}_{3} / \mathrm{BiOBr} / \mathrm{BC}$ for diclofenac removal under visible LED light irradiation: Mechanistic investigation and intermediates analysis. J. Hazard. Mater. 2019. [CrossRef]

109. Li, S.; Wang, Z.; Zhao, X.; Yang, X.; Liang, G.; Xie, X. Insight into enhanced carbamazepine photodegradation over biochar-based magnetic photocatalyst $\mathrm{Fe}_{3} \mathrm{O}_{4} / \mathrm{BiOBr} / \mathrm{BC}$ under visible LED light irradiation. Chem. Eng. J. 2019, 360, 600-611. [CrossRef]

110. Briscoe, J.; Marinovic, A.; Sevilla, M.; Dunn, S.; Titirici, M. Biomass-Derived Carbon Quantum Dot Sensitizers for Solid-State Nanostructured Solar Cells. Angew. Chem. Int. Ed. 2015, 54, 4463-4468. [CrossRef]

111. Hassan, M.; Gomes, V.G.; Dehghani, A.; Ardekani, S.M. Engineering carbon quantum dots for photomediated theranostics. Nano Res. 2018, 11, 1-41. [CrossRef]

112. Zhang, J.; Ma, Y.; Du, Y.; Jiang, H.; Zhou, D.; Dong, S. Carbon nanodots $/ \mathrm{WO}_{3}$ nanorods Z-scheme composites: Remarkably enhanced photocatalytic performance under broad spectrum. Appl. Catal. B Environ. 2017, 209, 253-264. [CrossRef]

113. Wang, T.; Liu, X.; Men, Q.; Ma, C.; Liu, Y.; Ma, W.; Liu, Z.; Wei, M.; Li, C.; Yan, Y. Surface plasmon resonance effect of $\mathrm{Ag}$ nanoparticles for improving the photocatalytic performance of biochar quantum-dot $/ \mathrm{Bi}_{4} \mathrm{Ti}_{3} \mathrm{O}_{12}$ nanosheets. Chin. J. Catal. 2019, 40, 886-894. [CrossRef]

(C) 2020 by the authors. Licensee MDPI, Basel, Switzerland. This article is an open access article distributed under the terms and conditions of the Creative Commons Attribution (CC BY) license (http://creativecommons.org/licenses/by/4.0/). 